\title{
KAMENÁRSKE ZNAČKY Z KAPLNKY SV. JAKUBA V BRATISLAVE
}

\author{
PETRA ŠIMONČIČOVÁ KOÓŠOVÁ - BRANISLAV LESÁK - DANIEL PIVKO
}

\begin{abstract}
Abstrakt: V predloženej štúdii sa vraciame k nálezu cintorínovej Kaplnky sv. Jakuba Staršieho na Svätovavrineckom predmestí v Bratislave. Centrom nášho záujmu bola tretia a štvrtá stavebná fáza kaplnky, datované do 15. storočia, do obdobia gotiky. Zaujímavým fenoménom tejto doby boli kamenárske značky, ktoré sa objavili na gotickej rímse kaplnky. Súbor osemnástich značiek zahŕňa aj d'alšie dve kategórie značiek, ktoré sa našli na sokli obvodového muriva a v sekundárnych polohách (zamurované do obvodového muriva lode a v zásype ossária). Nález sme zasadili do kontextu výstavby 15. storočia v stredovekej Bratislave, kde sme hladali aj analógie k značkám z Kaplnky sv. Jakuba.
\end{abstract}

Kl'účové slová: stredovek - cintorínová kaplnka - Bratislava-kamenárske značky.

\section{Masons' Marks in the Chapel of St. James, Bratislava}

Abstract: This study returns to the find of the cemetery Chapel of St. James the Elder in the St. Lawrence suburb, Bratislava. Research was focused on the third and fourth building phase of the chapel dated to the 15th century, to the Gothic period. One interesting phenomenon of this period were masons' marks that feature on the Gothic ledge of the chapel. The series of eighteen masons' marks includes another two categories of marks found on the perimeter masonry pedestal and in secondary positions (incorporated into the perimeter masonry of the nave and in the ossuary fill). The find was placed in the context of 15th-century building in medieval Bratislava, where analogies for the marks from the Chapel of St. James were sought as well.

Key words: Middle Ages - cemetery chapel-Bratislava-masons' marks.

Priestor dolnej časti námestia SNP v Bratislave bol archeologicky skúmaný v 20. storočí dva razy. V roku 1935 pri híbení suterénov pre Starú tržnicu boli objavené zvyšky Kostola sv. Vavrinca a odkrytá čast' tunajšieho cintorína (Mencl 1935, 466). Druhý výskum prebehol v rokoch 1994 až 1998, objavené boli pozostatky Kaplnky sv. Jakuba a jej predchádzajúce, staršie sakrálne stavby (Hoššo-Lesák 1996, 241). Predložená štúdia sa zameriava na druhú objavenú stavbu, presnejšie na gotickú fázu Kaplnky sv. Jakuba.

Pri výskume v 90. rokoch 20. storočia boli identifikované štyri stavebné fázy kaplnky. Prvú predstavuje predrománska rotunda (1100-1200/1250), druhú románsky karner (1200/1250-1400) a fázy III. (1400-1430/1460) aj IV. (1430/1460-1528) boli interpretované ako dve prestavby gotickej cintorínovej Kaplnky sv. Jakuba (Hoššo-Lesák 1996, 241-246). Kamenárske značky, o ktorých pojednáva predložená štúdia, boli primárne súčast’ou tretej stavebnej fázy kaplnky.

V období gotiky sa na Svätovavrineckom predmestí realizovali vel'ké prestavby sakrálnych stavieb. V 15. storočí prestavali tak farský Kostol sv. Vavrinca, ako aj Kaplnku sv. Jakuba. $\mathrm{V}$ archívnych prameňoch z tohto obdobia existuje mnoho dokladov o štedrých daroch bratislavských mešt’anov pre spomínaný farský kostol. Ku realizácii stavebných prác a prestavbe Kostola sv. Vavrinca došlo pravdepodobne až po pominutí husitského ohrozenia,t. j. po roku 1436 (Mencl 1935, 465).

V prvej polovici 15. storočia bol prestavaný aj románsky karner na gotický. Ossárium zostalo po prestavbe bezo zmeny, teda bez stavebných zásahov a nad’alej slúžilo pôvodného účelu. Prestavba sa dotkla len nadzemnej časti kaplnky. Bola vybudovaná obdížniková lod' s polygonálnou (oktogonálnou) apsidou. Nadzákladové murivo ukončoval sokel vysoký $0,5-0,8 \mathrm{~m}$, ktorý bol zvrchu lemovaný profilovanou kamennou rímsou. Vnútorná dížka lode je $6,6 \mathrm{~m}$ a šírka $5,58 \mathrm{~m}$. Śírka apsidy v mieste vít’azného oblúka je $3,65 \mathrm{~m}$ a jej dížka dosahuje $3,25 \mathrm{~m}$. Š́rka murív sa pohybuje medzi 0,95 až $1,1 \mathrm{~m}$. V tejto stavebnej fáze boli obvodové murivá zosilnené opornými piliermi. Do kaplnky sa vstupovalo zo západu, pričom vstup ohraničovali po oboch stranách kamenné polostĺpy s pätkami oktogonálneho prierezu. V súčasnosti sa zachovala len jedna, severná pätka (obr. 1,2). Na výstavbu cintorínovej kaplnky bol použitý sivý lomový vápe- 


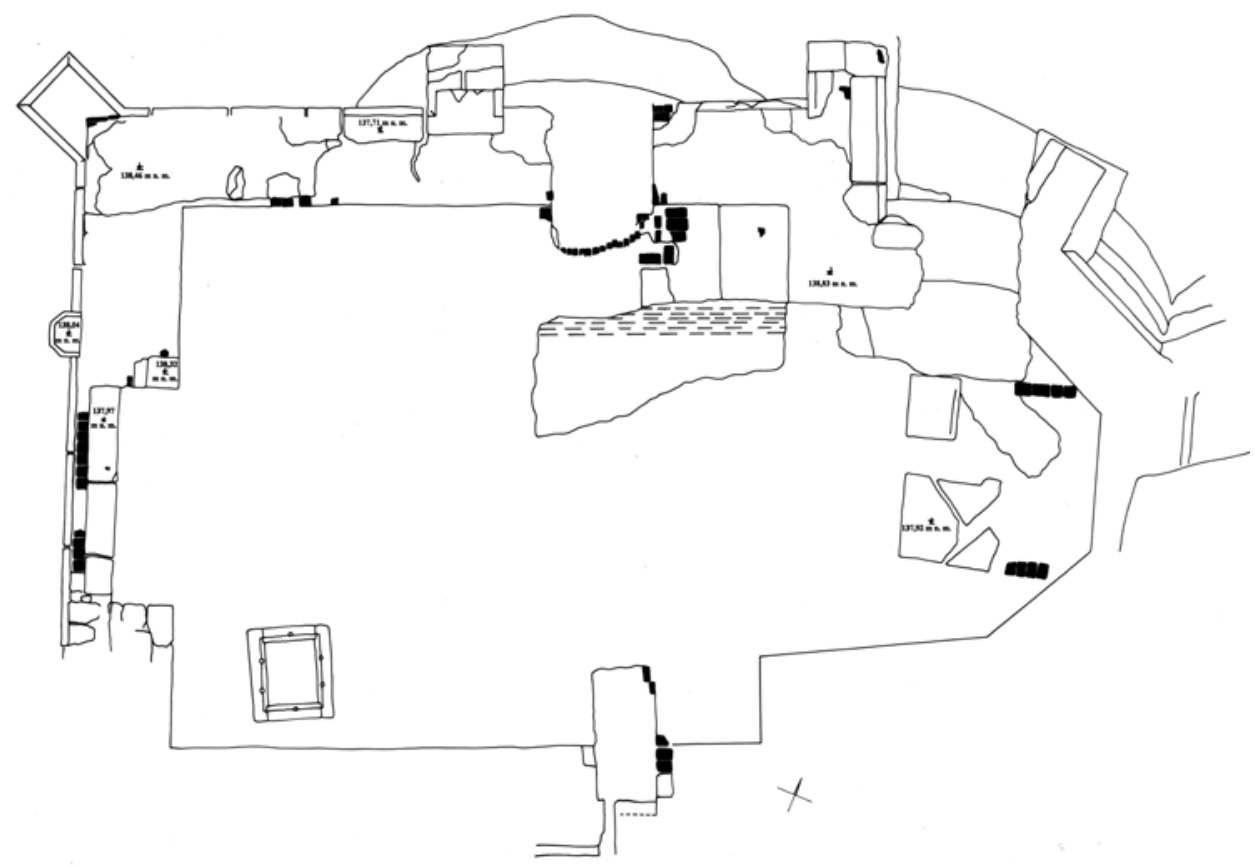

Obr. 1. Bratislava, Kaplnka sv. Jakuba staršieho. Pôdorys. Kresba J. Hoššo. Abb. 1. Bratislava, St. Jakobskapelle. Grundriss. Zeichnung J. Hoššo.

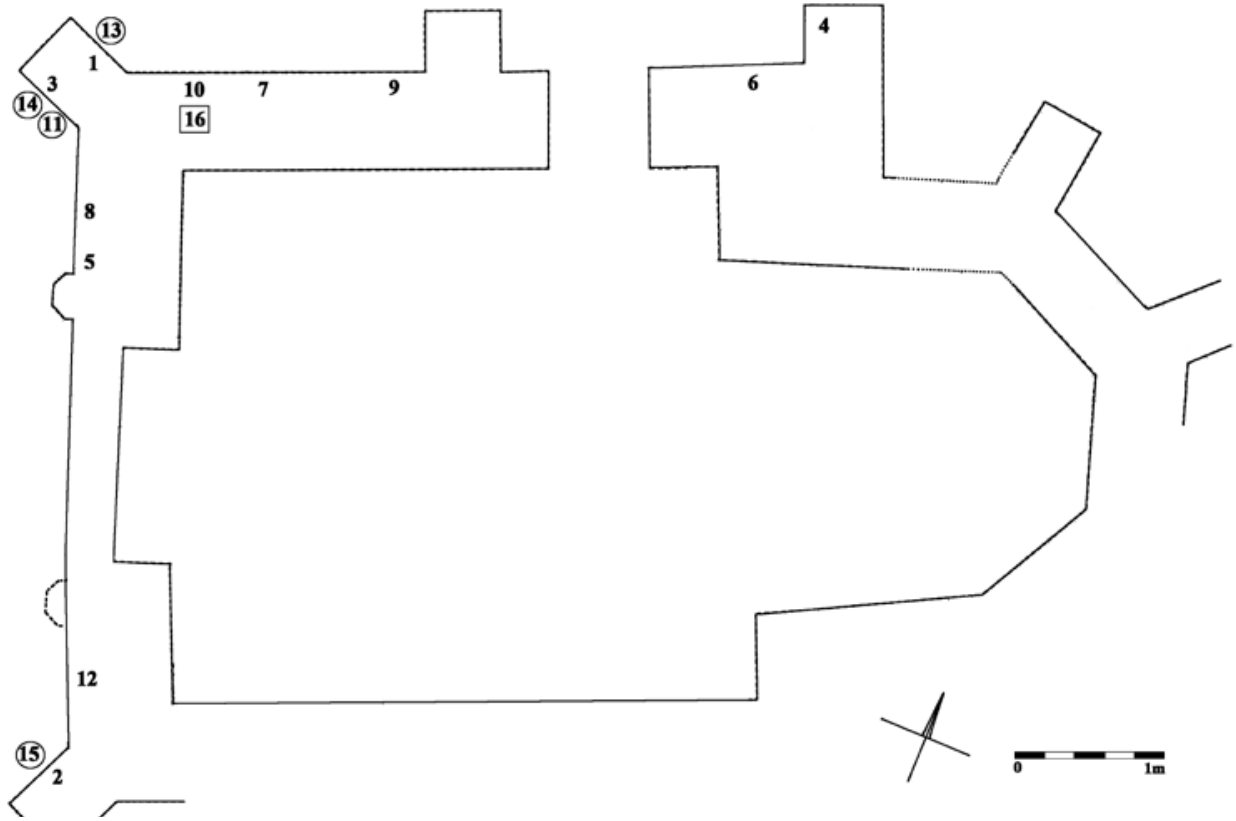

Obr. 2. Bratislava, Kaplnka sv. Jakuba. Lokalizácia kamenárskych značiek v rámci pôdorysu podl’a číselného označenia. V krúžku značky zo sokla, v štvorci z nadzemného muriva, jednoduché čísla zo soklovej rímsy. Kresba J. Hoššo, P. Šimončičová Koóšová.

Abb. 2. Bratislava, St. Jakobskapelle. Lokalisierung der Steinmetzzeichen im Grundriss entsprechend der jeweiligen Bezifferung. Im Kreis Zeichen vom Sockel, im Quadrat vom oberirdischen Gemäuer, einfache Zahlen vom Sockelsims. Zeichnung J. Hoššo, P. Šimončičová Koóšová. 
nec, doplnený tehlami a keramickou strešnou krytinou, ktorými sa vyrovnávali riadky. Murivá boli spájané sivou hrubozrnnou maltou (Hoššo-Lesák 1996, 245).

Kvôli nestálemu podložiu, ako aj položeniu gotických základov na staršie románske murivá došlo v pomerne krátkom čase $\mathrm{k}$ statickému narušeniu stavby a následne $\mathrm{k}$ jej prestavbe, označovanej ako „druhá gotická“. V tom čase sa terén zdvihol po úroveň soklovej rímsy a z pôdorysu zmizli oporné piliere. $\mathrm{K}$ väčším zmenám prišlo v priestoroch suterénu - kostnice. Bol zaklenutý valenou klenbou a úroveň staršej skládky pozostatkov zo starých hrobov bola oddelená tehlovou dlažbou, vytvorenou z gotických prstoviek oranžovej farby s rozmermi $25 \times 12 \times 5,5 \mathrm{~cm}$. Takto upravený priestor ossária slúžil svojmu účelu aj po zbúraní a zániku nadzemných častí sakrálnej stavby v rokoch 1528 až 1529. Zachované kamenné články, fresková výzdoba v interiéri i exteriéri sú dokladom honosnosti aj v záverečnej stavebnej fáze kaplnky (Hoššo-Lesák 1996, 246). Interiér lode mal v tomto období maltovú dlážku, do ktorej bola v priestore presbytéria zapustená oltárna menza. Mala pôdorys v tvare obdížnika a zachovali sa z nej dva na sebe uložené kamenné bloky z bieleho vápenca. Rozmery väčšieho spodného sú $90 \times 100 \times 18 \mathrm{~cm}$ a menšieho $63 \times 52 \times 14 \mathrm{~cm}$, ktorý je mierne vysunutý smerom na západ. V čase odkryvu bola spodná platňa už prasknutá.

Prvá zmienka o správcovi Kaplnky sv. Jakuba St. na Cintoríne sv. Vavrinca, mučeníka extra muros civitatis Posoniensis, Kristiánovi Mikulášovi z Rožňavy, pochádza z listiny bratislavskej kapituly z 26. marca 1422 (AMB, inv. č. 950). ${ }^{1}$

Patrocínium sv. Jakuba niesla kaplnka istotne už v prvej gotickej fáze a dokladá to vyššie uvedená prvá zmienka z roku 1422. V stredoveku bolo svätojakubské patrocínium vel'mi obl'úbené, tak v románskom, ako aj gotickom období. Kým v staršom, románskom období sa apoštolské patrocíniá, medzi nimi aj sv. Jakub starší, na území dnešného Slovenska len zavádzali, v období gotiky (2. polovica 13. až 1. polovica 16. storočia) bola ich obl'úbenost' na vrchole. Vo všeobecnosti bol sv. Jakub patrónom cestovatel'ov, pútnikov a v nemeckých oblastiach aj rytierov. Renesanciu uvedeného patrocínia mohol vyvolat' aj príchod nemeckých hostí do našich regiónov či fakt, že sv. Jakubovi zasvätená katedrála z Regensburgu bola v stredoveku obl'úbeným ciel’om pútnikov (Hudák 1984, 57-59; Slivka 2013, 121-122). Na území dnešného Slovenska mu bolo zasvätených viacero kostolov, ${ }^{2}$ napr. v Banskej Bystrici-Jakube-Ul’anke (okr. Banská Bystrica; zo začiatku 14. storočia), Levoči (okr. Levoča; prvá zmienka z roku 1245, gotický kostol zo začiatku 14. storočia na mieste románskeho), Prašiciach (okr. Topol'čany; doložený v roku 1332), Štvrtku na Ostrove (okr. Dunajská Streda; patrocínium sv. Jakuba doložené v roku 1245), františkánsky kostol v Trnave (okr. Trnava; z 1. polovice 14. storočia), v Tužine (okr. Prievidza; základy zo 14. storočia), vo Vel'kom Šariši (okr. Prešov; prvá zmienka z 1261), vo Volkovciach (okr. Zlaté Moravce; zo 14. storočia), Vrakúni (okr. Dunajská Streda; kostol z 11. storočia s patrocíniom doloženým v r. 1308) a v Želiezovciach (okr. Levice; postavený v 1. polovici 14. storočia; Hudák 1984, 125-126; Judák-Poláčik 2009, 131-132; Neumann 2014, 15).

Analógiou pravouhlej dispozície karnera z nášho územia je Karner sv. Michala v Trenčíne, datovaný rovnako na začiatok 15. storočia (Hoššo-Lesák 1996, 245). Výskum doložil kaplnku (karner) postavenú v 20. rokoch 15. storočia, eventuálne v období prestavby Trenčianskeho hradu za Štefana Zápol’ského v závere 15. storočia. Z Kaplnky sv. Michala pochádzajú aj kamenárske značky, ktoré však neboli publikované. Tvar sakrálneho priestoru, ako aj nájdené architektonické články podnietili autorov výskumu uvažovat' o podunajskom vplyve pri výstavbe stavby (Paulusová-Gojdič 1977, 14, 16). Na území dnešného Rakúska je pravouhlá dispozícia kostníc častejšia (Melzer-Reichinger 1990, 131).

\footnotetext{
1 Za vyhl'adanie tejto informácie d’akujeme PhDr. V. Obuchovej, CSc.

2 Patrocíniá sv. Jakuba sú doložené v Čakanoch (okr. Dunajská Streda; patrocínium cistercitského opátstva in insula Danubii doložené v 1274), Dolnej Strede (okr. Galanta; 1313), Dubnici nad Váhom (okr. Ilava; 1276), Dunajskej Strede (okr. Dunajská Streda; 1313), Krásnej nad Hornádom (okr. Košice; 1332-1335), Kysuckom Novom Meste (okr. Kysucké Nove Mesto; 1325), Nitre (okr. Nitra; 1332), Sennom (okr. Vel'ký Krtíš; 1288) a Trebel'ovciach (okr. Lučenec; 1332). Okrem uvedených je možné predpokladat' patrocínium na základe názvu obce alebo pečate v Jakubovanoch (okr. Liptovský Mikuláš), Vel'kom Grobe - villa sancti Jacobi (okr. Galanta; 1323; ?1245) a Jakovanoch (okr. Prešov; názov obce doložený v 1332; Hudák 1984, 125-126; Ruppeldtová 2006, 114-115; Judák-Poláčik 2009, 131-132).
} 


\begin{tabular}{|c|c|c|c|c|}
\hline $\begin{array}{l}\text { Č́slo } \\
\text { značky }\end{array}$ & Obrázok & Popis kvádra & Analógie & Literatúra \\
\hline \multirow{2}{*}{1} & & \multirow{2}{*}{$\begin{array}{l}\text { soklová rímsa; profilovaný } \\
\text { tupouhlý kamenný blok }- \text { roh } \\
\text { piliera; značka dolu na kraji } \\
\text { dlhšieho ramena profilovanej } \\
\text { strany; } 25+51 \times 23,5 \times(40) \mathrm{cm}\end{array}$} & $\begin{array}{l}\text { Viedeň, kostol minoritov, č. } 756 \\
\text { (opačná) }\end{array}$ & Ržiha 1989, Taf. 39 \\
\hline & & & $\begin{array}{l}\text { Regensburg, dóm, č. } 865 \\
\text { (podobná) }\end{array}$ & Ržiha 1989, Taf. 47 \\
\hline \multirow{2}{*}{2} & & \multirow{2}{*}{$\begin{array}{l}\text { soklová rímsa; profilovaný } \\
\text { tupouhlý kamenný blok }- \text { roh } \\
\text { piliera; značka dolu pri kraji } \\
\text { dlhšieho ramena profilovanej } \\
\text { strany; } 17+44 \times 24 \times(40) \mathrm{cm}\end{array}$} & $\begin{array}{l}\text { Viedeň, kostol minoritov, č. } 756 \\
\text { (opačná) }\end{array}$ & Ržiha 1989, Taf. 39 \\
\hline & & & $\begin{array}{l}\text { Regensburg, dóm, č. } 865 \\
\text { (podobná) }\end{array}$ & Ržiha 1989, Taf. 47 \\
\hline \multirow{2}{*}{3} & & \multirow{2}{*}{$\begin{array}{l}\text { soklová rímsa; profilovaný } \\
\text { tupouhlý kamenný blok }- \text { roh } \\
\text { piliera; značka dolu uprostred } \\
\text { dlhšieho ramena profilovanej } \\
\text { strany; } 49+24 \times 24 \times(40) \mathrm{cm}\end{array}$} & $\begin{array}{l}\text { Viedeň, kostol minoritov, č. } 756 \\
\text { (opačná) }\end{array}$ & Ržiha 1989, Taf. 39 \\
\hline & & & $\begin{array}{l}\text { Regensburg, dóm, č. } 865 \\
\text { (podobná) }\end{array}$ & Ržiha 1989, Taf. 47 \\
\hline \multirow{6}{*}{4} & & \multirow{6}{*}{$\begin{array}{l}\text { soklová rímsa; rohový profi- } \\
\text { lovaný rovný kamenný blok; } \\
\text { značka na neprofilovanej strane; } \\
(50) \times 24 \times 25 \mathrm{~cm}\end{array}$} & Regensburg, dóm, č. 628 & Ržiha 1989, Taf. 32 \\
\hline & & & Bratislava, hrad, č. 130 (opačná) & Fiala 1969 , obr. 7 \\
\hline & & & $\begin{array}{l}\text { Viedeň, Stefansdom, č. } 92 \\
\text { (opačná) }\end{array}$ & Ržiha 1989, Taf. 5 \\
\hline & & & $\begin{array}{l}\text { Viedeň, Maria Stiegen, č. } 153 \\
\text { (opačná) }\end{array}$ & Ržiha 1989, Taf. 9 \\
\hline & & & Praha, sv. Vít, č. 217 (opačná) & Ržiha 1989, Taf. 12 \\
\hline & & & $\begin{array}{l}\text { Košice, sv. Alžbeta, č. } 429 \\
\text { (podobná) }\end{array}$ & Ržiha 1989, Taf. 22 \\
\hline \multirow{4}{*}{5} & \multirow{4}{*}{ ๙ } & \multirow{4}{*}{$\begin{array}{l}\text { soklová rímsa; profilovaný rov- } \\
\text { ný kamenný blok; značka dolu } \\
\text { uprostred profilovanej strany; } \\
44 \times 24 \times(40) \mathrm{cm}\end{array}$} & Bratislava, hrad, č. 130 (opačná) & Fiala 1969, obr. 7 \\
\hline & & & $\begin{array}{l}\text { Viedeň, Stefansdom, č. } 92 \\
\text { (podobná) }\end{array}$ & Ržiha 1989, Tab. 5 \\
\hline & & & $\begin{array}{l}\text { Viedeň, Maria Stiegen, č. } 153 \\
\text { (podobná) }\end{array}$ & Ržiha 1989, Taf. 9 \\
\hline & & & Praha, sv. Vít, č. 217 (podobná) & Ržiha 1989, Tab. 12 \\
\hline \multirow[b]{3}{*}{6} & & \multirow{3}{*}{$\begin{array}{l}\text { soklová rímsa; profilovaný rov- } \\
\text { ný kamenný blok; značka dolu } \\
\text { uprostred profilovanej strany; } \\
70 \times 24 \times(40) \mathrm{cm}\end{array}$} & Viedeň, Stefansdom, č. 26 & Ržiha 1989, Taf. 2 \\
\hline & & & Praha, hrad, č. 247 (podobná) & Ržiha 1989, Taf. 13 \\
\hline & & & Bratislava, hrad, č. 37 (podobná) & Fiala 1969, obr. 6 \\
\hline \multirow{3}{*}{7} & & \multirow{3}{*}{$\begin{array}{l}\text { soklová rímsa; profilovaný rov- } \\
\text { ný kamenný blok; značka dolu } \\
\text { uprostred profilovanej strany; } \\
80 \times 24 \times(40) \mathrm{cm}\end{array}$} & $\begin{array}{c}\text { Bratislava, sv. Martin - veža, } \\
\text { č. } 8\end{array}$ & $\begin{array}{c}\text { Rybáriková-Serdahely } \\
1989, \text { obr. } 11,120\end{array}$ \\
\hline & & & Viedeň, Stefansdom, č. 36 & Ržiha 1989, Tab. 3 \\
\hline & & & $\begin{array}{l}\text { Viedeň, Maria Stiegen, č. } 139 \\
\text { (opačná) }\end{array}$ & Ržiha 1989, Taf. 8 \\
\hline \multirow{3}{*}{8} & \multirow{3}{*}{2} & \multirow{3}{*}{$\begin{array}{l}\text { soklová rímsa; profilovaný rov- } \\
\text { ný kamenný blok; značka dolu } \\
\text { uprostred profilovanej strany; } \\
72,5 \times 24 \times(40) \mathrm{cm}\end{array}$} & $\begin{array}{c}\text { Bratislava, sv. Martin - veža, } \\
\text { č. } 8\end{array}$ & $\begin{array}{c}\text { Rybáriková-Serdahely } \\
1989 \text {, obr. } 11,120\end{array}$ \\
\hline & & & Viedeň, Stefansdom, č. 36, & Ržiha 1989, Tab. 3 \\
\hline & & & $\begin{array}{c}\text { Viedeň, Maria Stiegen, č.139 } \\
\text { (opačná) }\end{array}$ & Ržiha 1989, Taf. 8 \\
\hline 9 & $\mathfrak{F}$ & $\begin{array}{l}\text { soklová rímsa; profilovaný rov- } \\
\text { ný kamenný blok; značka dolu } \\
\text { uprostred profilovanej strany; } \\
79 \times 24 \times(40) \mathrm{cm}\end{array}$ & - & \\
\hline
\end{tabular}




\begin{tabular}{|c|c|c|c|c|}
\hline $\begin{array}{l}\text { Čislo } \\
\text { značky }\end{array}$ & Obrázok & Popis kvádra & Analógie & Literatúra \\
\hline 10 & & $\begin{array}{l}\text { soklová rímsa; profilovaný } \\
\text { rovný kamenný blok; značka } \\
\text { dolu uprostred profilova- } \\
\text { nej strany tažko čitatel'ná; } \\
80 \times 24 \times(40) \mathrm{cm}\end{array}$ & Bratislava, hrad, č. 55 (podobná) & Fiala 1969, obr. 6 \\
\hline 11 & & $\begin{array}{l}\text { sokel; opracovaný kváder; } \\
\text { značka (?) dolu na okraji (spolu } \\
\text { s č. } 14) ; 70 \times 40 \times 31 \mathrm{~cm}\end{array}$ & - & \\
\hline 12 & & $\begin{array}{l}\text { soklová rímsa; profilovaný rov- } \\
\text { ný kamenný blok; zle čitatelná } \\
\text { značka dolu uprostred profilo- } \\
\text { vanej strany; } 119 \times 24 \times(40) \mathrm{cm}\end{array}$ & $\begin{array}{l}\text { Bratislava, sv. Martin, klenba } \\
\text { lode, č. } 8 \text { (podobná) }\end{array}$ & $\begin{array}{c}\text { Rybáriková-Serdahely } \\
1989, \text { obr. } 2,114\end{array}$ \\
\hline 13 & & $\begin{array}{l}\text { sokel; opracovaný kváder; } \\
\text { značka uprostred na okraji; } \\
69 \times 40 \times 29 \mathrm{~cm}\end{array}$ & - & \\
\hline 14 & & $\begin{array}{l}\text { sokel; opracovaný kváder; znač- } \\
\text { ka dolu na okraji (spolu s č. 11); } \\
70 \times 40 \times 31 \mathrm{~cm}\end{array}$ & - & \\
\hline 15 & & $\begin{array}{l}\text { sokel; opracovaný kváder; } \\
\text { značka uprostred }-? \text { zvetraná; } \\
63 \times 22 \times ? \mathrm{~cm}\end{array}$ & $\begin{array}{l}\text { Bratislava, sv. Martin, klenba } \\
\text { lode, č. } 25 \text { (podobná) }\end{array}$ & $\begin{array}{c}\text { Rybáriková-Serdahely } \\
1989, \text { obr. } 4,115\end{array}$ \\
\hline \multirow[b]{2}{*}{16} & & \multirow{2}{*}{$\begin{array}{l}\text { S murivo lode; sekundárny } \\
\text { kamenný blok zamurovaný; } \\
25 \times 20,5 \times ? \mathrm{~cm}\end{array}$} & $\begin{array}{c}\text { Bratislava, hrad, osadzovacie } \\
\text { značky }\end{array}$ & Fiala 1969, obr. 4 \\
\hline & & & Viedeň, Stefansdom, č. 2? & Ržiha 1989, Taf. 1 \\
\hline \multirow[b]{2}{*}{17} & & \multirow{2}{*}{$\begin{array}{l}\text { zásyp ossária; článok rebra (?), } \\
\text { opracovaný na šest'hran, na } \\
\text { povrchu biela omietka, poly- } \\
\text { chrómna mal'ba - svetloružový } \\
\text { náter s červenou šikmou zdvoje- } \\
\text { nou linkou - cikcak; značka na } \\
\text { kontaktnej ploche (na opačnej } \\
\text { strane č. } 18) ; 38 \times 23 \times 21 \mathrm{~cm}\end{array}$} & $\begin{array}{l}\text { Bratislava, hrad, osadzovacie } \\
\text { značky }\end{array}$ & Fiala 1969, obr. 4 \\
\hline & $L$ & & Viedeň, Stefansdom, č. 2? & Ržiha 1989, Taf. 1 \\
\hline 18 & & $\begin{array}{l}\text { zásyp ossária; článok rebra (?), } \\
\text { opracovaný na šest'hran, na } \\
\text { povrchu biela omietka, poly- } \\
\text { chrómna mal'ba - svetloružový } \\
\text { náter s červenou šikmou zdvoje- } \\
\text { nou linkou - cikcak; značka na } \\
\text { kontaktnej ploche (na opačnej } \\
\text { strane č. 17); } 38 \times 23 \times 21 \mathrm{~cm}\end{array}$ & Devín, hrad - studňa, vrstva č. 3 & Piffl 2007, 203 \\
\hline
\end{tabular}

Tab. 1. Kamenárske značky $z$ Kaplnky sv. Jakuba v Bratislave, popis a analógie.

Tab. 1. Steinmetzzeichen aus der St. Jakobskapelle in Bratislava, Beschreibung und Analogien. 
Rozbor kamenárskych značiek (tab. 1, obr. 3-5)

Kaplnka sv. Jakuba v Bratislave nebola odkrytá v celom pôdoryse. Kompletný odkryv sa realizoval pozdíž severného obvodového muriva, viac-menej bola odkrytá západná stena kaplnky po juhozápadný oporný pilier, na východe bola z vonkajšej strany odkrytá asi polovica apsidy. Juhovýchodná čast' apsidy a južná obvodová stena zostali z vonkajšej strany neodkryté. Na vstupnom západnom schodisku ani na severnej pätke piliera pri vstupe sme značky nenašli. $\mathrm{K}$ soklovej rímse $\mathrm{z}$ vonkajšej strany presbytéria nie je dobrý prístup, preto sme $\mathrm{v}$ tomto priestore neidentifikovali žiadne kamenárske značky. V našej štúdii sa zaoberáme tými, ktoré boli identifikované na profilovanej soklovej rímse severného a západného obvodového muriva, patriacej ku tretej stavebnej fáze Kaplnky sv. Jakuba (značky č. 1-10, 12). Štyri značky sú na opracovaných kameňoch tvoriacich sokel (značky č. 13-15, 11) a jedna na kameni zamurovanom v severnom obvodovom murive lode (značka č. 16). Okrem toho sme do skúmaného súboru zahrnuli značky (č. 17-18) nájdené na kamennom článku pochádzajúcom zo zásypu ossária. Kamenárske značky sme rozdelili do troch kategórií.
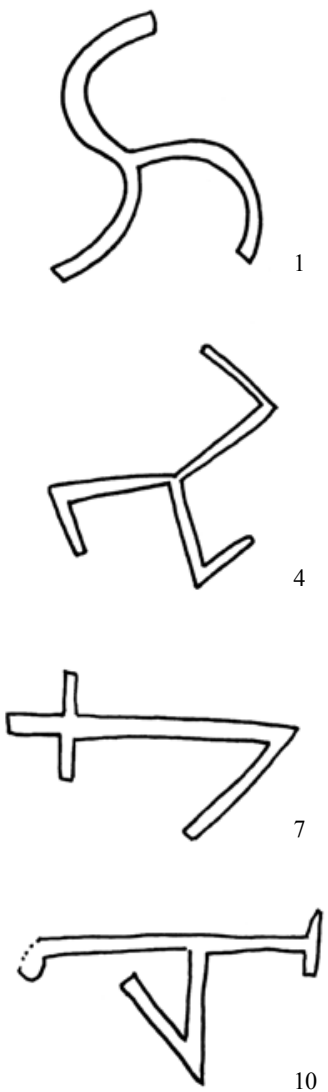
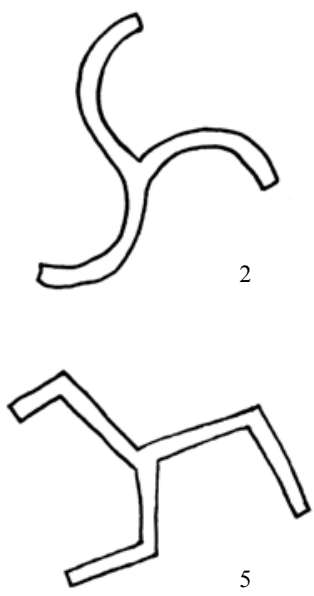

5

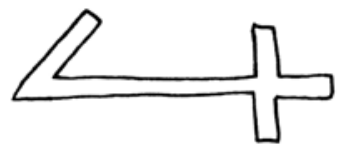

8

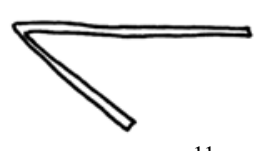

11
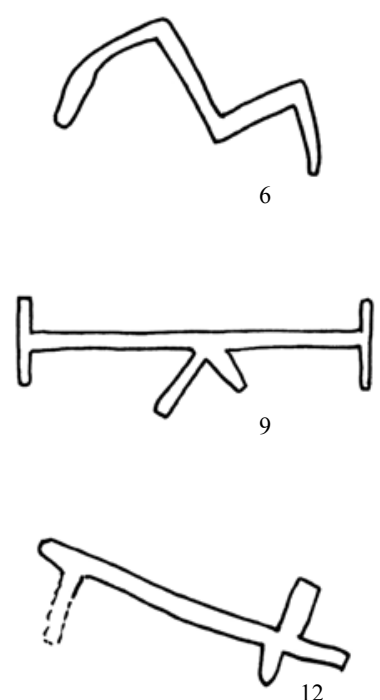

12

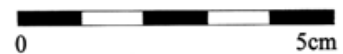

Obr. 3. Bratislava, Kaplnka sv. Jakuba. Kamenárske značky z gotickej rímsy, autorské značky č. 1-12. Kresba P. Šimončičová Koóšová.

Abb. 3. Bratislava, St. Jakobskapelle. Steinmetzzeichen vom gotischen Sims, personenbezogene Steinmetzzeichen Nr. 1-12. Zeichnung P. Šimončičová Koóšová. 
Prvá, najpočetnejšia skupina predstavovala značky určujúce autorstvo (obr. 3). Zdá sa, že každý kamenný článok soklovej rímsy bol označený menšou kamenárskou značkou s vel'kost'ou okolo $5 \mathrm{~cm}$. Dôvodov, prečo na niektorých blokoch chýbajú, môže byt' viacero. V prípade okraja severozápadného oporného piliera, piliera uprostred severnej steny a prvého kamenného bloku východne od vstupu do ossária môže byt' dôvodom menšia či väčšia deštrukcia kameňov rímsy. Uprostred severného obvodového muriva chýba značka aj na jednom menšom kamennom článku s dížkou $37 \mathrm{~cm}$. V tomto prípade by sme mohli uvažovat', že kamene menšej vel'kosti sa neoznačovali. Dížka označených kamenných článkov je nad $44 \mathrm{~cm}$ (najmenší kameň so značkou č. 5). Najpočetnejšie sú značky č. 1-3, ktoré sa našli na osobitnom type kamenného článku, ktorý tvoril tupouhlý roh v mieste dosadania piliera k lodi kaplnky. Mal nerovnako dlhé ramená, pričom označené bolo v spodnej časti dlhšie z nich. Analógie majú v Minoritskom kostole vo Viedni a dóme v Regensburgu (tab. 1). Zjavne išlo o kamenára, ktorý sa aspoň v prípade Kaplnky sv. Jakuba venoval dodávke kameňov jedného typu. Ostatné značky sa našli len po jednom a okrem č. 4 sú aplikované na rovných profilovaných článkoch rímsy. Značka č. 4 sa našla na rovnom rohovom profilovanom článku piliera. Zaujímavé je, že v tomto prípade bola značka na menej viditel'nom mieste - na boku, nie pod profiláciou. Analógie ku značkám poznáme z Bratislavského hradu, Dómu sv. Martina v Bratislave, ale aj z Viedne, Prahy či Regensburgu (tab. 1).

Druhá kategória (obr. 4) pozostáva z vel'kých značiek na opracovaných kamenných kvádroch v soklovej časti severozápadného oporného piliera (č. 13, 14). Ich vel'kost' sa pohybuje okolo 9 až $10 \mathrm{~cm}$. Trošku menšia, no nie úplne čitatel'ná je značka č. 15 na kamennom kvádri juhozápadného oporného piliera, ktorej vel'kost' sa pohybuje okolo $7 \mathrm{~cm}$. Isté podobnosti vykazuje so značkou v klenbe lode Dómu sv. Martina v Bratislave (tab. 1). Zaujímavý je kváder so značkou č. 14, na ktorom sa našla aj otázna menšia značka č. 11. Nie je úplne zrejmé, či bol tento blok označený dvomi značkami, alebo je menšia iba nedokončenou autorskou značkou. Nezvykle vel'ká značka sa našla na jednom kvádri na murive predbránia Rybárskej brány, pri ktorej A. Fiala predpokladal, že mohlo íst' o kamenára zodpovedného za celok. Vtedy nebolo nutné menšími označovat' jednotlivé kamene. Väčšia značka mohla označovat' majstra kamenára. Príklady poznáme aj z Dómu sv. Martina v Bratislave, kde okrem menších značiek na kruhovom schodisku a hornom portáli vo veži je na portáli aplikovaná navyše vel'ká značka (Fiala 1969, 19; 2001; Rybáriková-Serdahely 1989, 111).

Poslednou, tret’ou kategóriou (obr. 5) je značka č. 16, nájdená na kameni zamurovanom v severnej stene kaplnky nad soklovou rímsou. Jej vel'kost' je okolo $7 \mathrm{~cm}$ a tvarovo sa podobá na jednu zo značiek (č. 17) z kamenného článku nájdeného v sekundárnej polohe, v zásype ossária Kaplnky sv. Jakuba (v súčasnosti deponovaný v priestoroch Mestského ústavu ochrany pamiatok Bratislava). Je možné, že aj v murive kaplnky bol zamurovaný článok zo staršej fázy tunajšej stavby, a teda sa jedná o starší typ značky. Spomínaný kamenný článok, pravdepodobne z rebra zdobeného polychrómnou mal'bou, nájdený $\mathrm{v}$ zásype ossária, bol označený dvomi značkami (č. 17, 18) na miestach dotyku s d'alšou čast'ou rebra. V zozname A. Piffla z Devínskej hradnej studne je vo vrstve č. 3 zachytená značka (Piffl 2007, 203) analogická k druhej značke (č. 18). Značky z devínskej studne boli interpretované ako montážne (Plachá-Hlavicová 2003, 79-80). Na styčných plochách jednotlivých článkov vysekávali kamenári jednoduché značky, ktoré mali ul'ahčit' osadzovanie kameňov. Takéto príklady máme aj z Bratislavského hradu (Fiala 1969, 18, obr. 4). Vo funkčnej polohe ani jedna zo značiek (č. 16-18) na sekundárne nájdených kamenných článkoch z Kaplnky sv. Jakuba nebola viditel'ná, teda nemohla byt' viditel'ným podpisom kamenára ako pri značkách na sokli či profilovanej rímse. Preto ich zarad’ujeme do kategórie montážnych - osadzovacích značiek.

Remeselnícka značka patrila medzi právne nástroje, ktorými bolo možné preukázat' vlastníctvo, svoj nárok či záväzok. Bolo možné ju dokonca dedit'. Kamenár však na rozdiel od iných remeselníkov používajúcich značky na označovanie svojich výrobkov musel putovat' v určitom priestore. Mohol sa dostat' do prostredia, kde rovnakú značku používal iný remeselník, čo môže

3 Mätúce je, že neskôr publikovaný súpis značiek z Devínskej hradnej studne (Plachá-Hlavicová 2003, obr. 66, 81) nie je úplne totožný so zoznamom A. Piffla. 

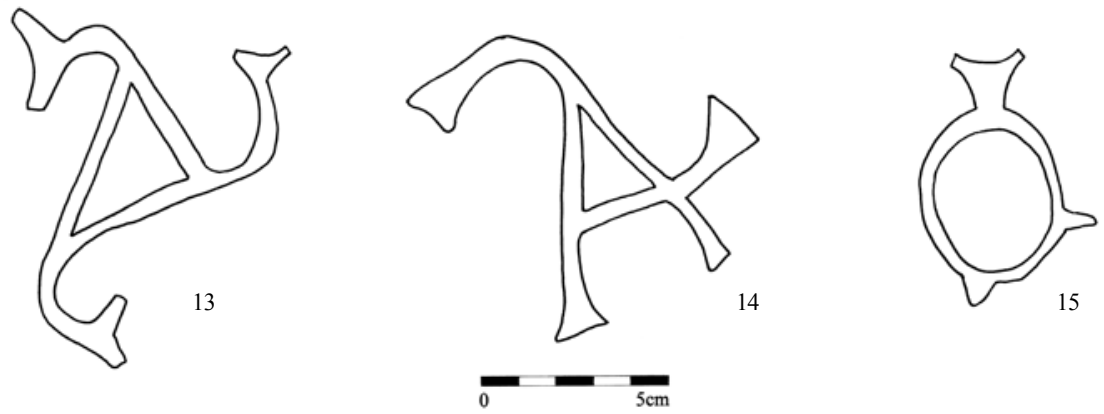

Obr. 4. Bratislava, Kaplnka sv. Jakuba. Kamenárske značky zo sokla, vel’ké značky č. 13-15. Kresba P. Šimončičová Koóšová. Abb. 4. Bratislava, St. Jakobskapelle. Steinmetzzeichen vom Sockel, große Zeichen Nr. 13-15. Zeichnung P. Šimončičová Koóšová.

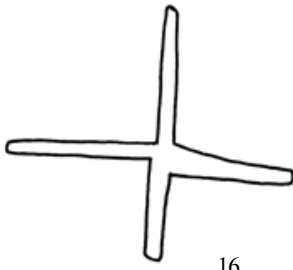

16
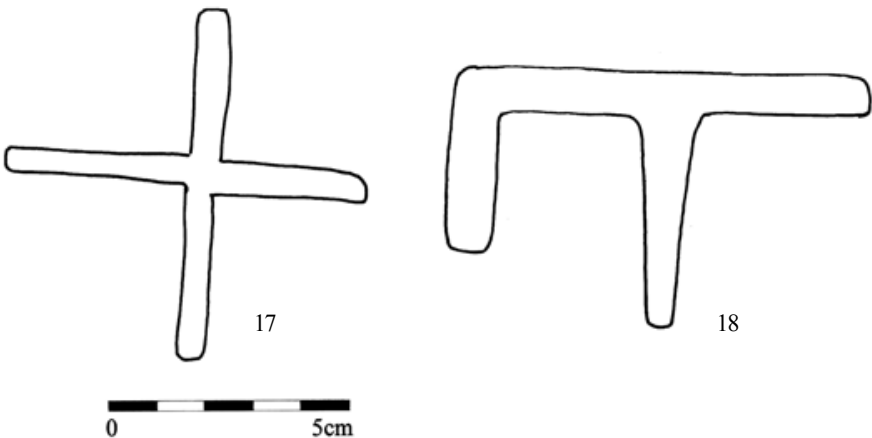

Obr. 5. Bratislava, Kaplnka sv. Jakuba. Kamenárske značky zo sekundárnych polôh, montážne značky č. 16-18. Kresba P. Šimončičová Koóšová.

Abb. 5 Bratislava, St. Jakobskapelle. Steinmetzzeichen aus Sekundärlagen, Versatzzeichen Nr. 16-18. Zeichnung P. Šimončičová Koóšová.

byt’ pri jeho identifikácii mätúce (Masuch 1998, 82-84). Kamenárska značka bola autogramom stredovekého kamenára. S jej rozborom bolo možné odvodit' koreň huty, v ktorej remeselník pôsobil a aké vandrovky vykonal (Baur 1974, VIII; Rybáriková 1984, 31; Rybáriková-Serdahely 1989, 110-111). Systémy stredovekých kamenárskych značiek je možné rozdelit' do troch časových období: rané na prelome 12. a 13. storočia, prechodné okolo roku 1400 a neskoré (16. storočie; Masuch 1998, 86). Románske kamenárske značky zachytené v rôznych častiach strednej Európy často znázorňujú kamenárske nástroje a pomôcky (Kukal-Malina-Malinová-Tesařová 1989, 184).

V Bratislave sa kamenárske značky našli na gotických sakrálnych i svetských stavbách, konkrétne v Dóme sv. Martina, kostoloch rehole klarisiek a františkánov, na Bratislavskom hrade či Rybárskej bráne, tvoriacej súčast' mestských hradieb. Z okolia stredovekej Bratislavy sme zo skúmaného horizontu hladali analógie na hrade a v kostole v Devíne či priamo v mieste pôsobenia kamenárskej huty vo Viedni, v Katedrále sv. Štefana (Stefansdom). Ich variabilita je však vel'mi široká a iba niektoré možno považovat' za analógie ku značkám z Kaplnky sv. Jakuba.

V Bratislave a okolí prebiehala v 15. storočí čulá výstavba. Vel'ká prestavba prebehla na Bratislavskom hrade v období vlády Žigmunda Luxemburského, v 30. rokoch 15. storočia. V tom čase bolo prebudované západné a severné opevnenie s dvomi delovými baštami a postavený bol nový palác. Práce viedol kamenársky majster Konrád z Erlingu, ktorému v roku 1434 podliehali 
tri vel'ké kamenárske huty. To predstavovalo ca $300^{4}$ remeselníkov. Kamenárski tovariši v počte 32 až 40 boli vedení priamo majstrom Konrádom. Ďalší kamenári a lámači kameňa (ca 28-40) pracovali pod dozorom majstra Prokopa. Tesárov v počte šest' až trinást' viedol majster Ján. Do vyššie uvedeného súčtu sú zarátané aj iné profesie podiel'ajúce sa na stavbe hradu. V jednom týždni tu naraz pracovalo priemerne 100-130, maximálne však 154 remeselníkov, ktorí boli vyplácaní v troch kategóriách s rôznou výškou mzdy. Boli sem povolaní kamenári z Bavorska i Budína. Výstavba opevnenia a paláca v Budíne prebiehala v rokoch 1410-1426 a v roku 1432 tam ostalo pracovat' už iba málo remeselníkov. Hrubá stavba Bratislavského hradu bola ukončená v roku 1437. Po smrti Žigmunda Luxemburského sa stavebná huta rozpadla, no kamenári našli svoje uplatnenie na iných stavbách v meste a okolí (Mencl-Menclová 1936, 66, 69; Fiala 1969, 13-15, 46; Holčík-Štefanovičová 1982, 40-42, 48-49; Horváth-Lehotská-Pleva 1982, 82; Rybáriková 1984, 119; Žáry-Bagin-Rusina-Toranová 1990, 49; Fiala-Semanko 1993, 22; Plachá-Hlavicová 2003, 72; Špiesz 2008, 180). Celkovo bolo na hrade identifikovaných 191 typov kamenárskych značiek. V studni vytesanej do skalného brala v rokoch 1434-1436 identifikoval A. Piffl v roku 1957 na kamenných kvádroch 25 druhov značiek, na základe ktorých predpokladal účast' 22 kamenárov na jej stavbe. Niektoré z nich dokladajú prácu tých istých kamenárov aj na iných častiach hradu (Fiala 1969, 19-25, 43-44; 2008, 40; Piffl 2007, 108-109; Holčík-Štefanovičová 1982, 50; Fiala-Semanko 1993, 22; Havlík-Sabadošová 2012, 172).

Prestavba farského Kostola sv. Martina (dnes Dóm sv. Martina) ${ }^{5}$ prebiehala v prvej polovici 15. storočia. Za jej začiatok možno považovat' rok 1411, kedy boli vyhlásené odpustky za prispenie na výstavbu kostola. Práce však mohli byt' prerušované kvôli ohrozeniu mesta husitmi. Podnetom na prestavbu boli časté návštevy Žigmunda Luxemburského v Bratislave, počas ktorých sa zúčastňoval omší. Farský Kostol sv. Martina bol najbližšie, po ceste z hradu. V tomto mieste pristavili k boku svätomartinskej veže královskú kaplnku, zasvätenú neskôr sv. Jozefovi. Využívala ju aj vdova po českom královi Václavovi IV., Žofia, ktorá prežila posledné roky svojho života v opatere rehole klarisiek v Bratislave (1423-1428). Je možné, že s ňou prišli aj českí kamenári, ktorí pracovali na objednávky bratislavskej kapituly a mesta. Počas prestavby hradu sa na stavbe farského Kostola sv. Martina v poslednom desat'ročí vlády Žigmunda Luxemburského mohli zúčastnit' remeselníci povolaní z Budína a snád' aj z Košíc. Práce zavŕšila výstavba trojlod’ového chrámu zaklenutého v roku 1452, kedy bol kostol opätovne vysvätený. Analógie ku našim značkám (č. 7, 8, 12,15) máme z klenby lode stavanej v rokoch 1435-1452 a z veže sčasti datovanej svojím vznikom do rokov 1423-1440. Na výstavbe cisárskej kaplnky a podvežia sa zúčastňovali kamenári z hradnej huty pod vedením Konráda z Erlingu (Mencl-Menclová 1936, 64; Horváth-Lehotská-Pleva 1982, 88-89; Rybáriková 1984, 34, 76, 104; Rybáriková-Serdahely 1989, 109; Žáry-Bagin-Rusina-Toranová 1990, 36-38, 45-47, 49, 52, 60; Špiesz 2008, 109110). Výstavba františkánskeho kostola bola ukončená na prelome 13. a 14. storočia. V rokoch 1410-1420 bola naň z južnej strane lode pristavená šest'boká vežička. K opravám a prestavbe františkánskeho kláštora došlo po požiari 6. júla 1439. Vysviacka nového kláštora nasledovala až v decembri 1455. Ďalší požiar zasiahol kostol aj kláštor v roku 1480, po ňom v závere 15. storočia mnohí bratislavskí meštania venovali $\mathrm{v}$ testamentoch peniaze na obnovu oboch budov (Mencl-Menclová 1936, 9, 74; Horváth-Lehotská-Pleva 1982, 86; Rybáriková 1984, 111; Špiesz 2008 , 111). Výstavba kostola klarisiek začala na prelome 13. a 14. storočia. V druhej polovici 14. storočia bol kostol zaklenutý a rozšírilo sa presbytérium. Podobne ako vo františkánskom, i v klariskom kostole okolo roku 1400 osadili na juhozápadné nárožie lode gotickú pät'bokú vežičku. K prestavbám došlo po požiari v roku 1515 (Horváth-Lehotská-Pleva 1982, 86; Rybáriková 1984, 116; Špiesz 2008, 111). V 15. storočí sa opravoval aj dnes už zaniknutý farský Kostol sv. Michala (Špiesz 2008, 113).

4 V. Plachá a J. Hlavicová uvádzajú 90 až 100 remeselníkov (Plachá-Hlavicová 2003, 72). A. Špiesz ujasňuje tieto počty nasledovne - v roku 1434 na hrade pracovalo 112 kamenárov a murárov a d’alších 163 pomocných robotníkov. Na čele stál stavebný majster s tromi paliermi, pričom za kamenárske práce bol zodpovedný český majster Prokop (Špiesz 2008, 180).

5 Pri popisovaní súčasného stavu používame termín Dóm sv. Martina, no v prípade historických reálií vzt'ahujúcich sa $\mathrm{k} 15$. storočiu nebol tento kostol biskupským sídlom, a teda ho nemôžeme takto označovat'. Plnil funkciu kapitulského a mestského farského kostola. Z tohto dôvodu sa nám zdá správnejšie používat' termín Kostol sv. Martina. 
Pravdepodobne po roku 1436 došlo aj k prestavbe v tesnej blízkosti Kaplnky sv. Jakuba, v tunajšom farskom Kostole sv. Vavrinca. Bratislava mala v tom čase tri farské kostoly sv. Martina, sv. Vavrinca a sv. Michala. V 15. storočí vd’aka štedrosti farníkov a bratislavských meštanov bol Kostol sv. Vavrinca vystavaný do úctyhodných rozmerov s desiatimi kaplnkami a vežou s tromi zvonmi. Bol vel'mi navštevovaným a jeho spevácky zbor sa postupne rozrástol z dvanástich na dvadsat' štyri členov. Farári zo sv. Vavrinca boli členmi bratislavskej kapituly a do funkcie ich dosadzovala mestská rada. Pôsobili aj ako kurátori arcibiskupského desiatku (Mencl 1935, 465-466; Mencl-Menclová 1936, 74; Špiesz 2008, 112). Význam predmestí Bratislavy potvrdzuje odpis mestského privilégia Ondreja III., ktorý dal vyhotovit' Karol Róbert v roku 1313. Od pôvodného textu z roku 1291 sa líši len minimálne. V štyroch prípadoch doplnil pisár k „mestu“ aj ,,predmestia“. Z toho vyplýva, že král’ovské privilégium platilo rovnako in eadem civitate vel in suburbio ipsius civitatis. Už v pôvodnom privilégiu z roku 1291 sa uvádza, že ktokol'vek z hostí sa usadí na predmestí, má užívat' rovnaké práva ako meštania (Mencl-Menclová 1936, 21; Horváth 1991, 11-12).

Výstavba a opevňovanie mesta i hradu boli od roku 1423 podnietené blízkostou husitského nebezpečenstva a zintenzívnili sa od januára 1428, kedy husiti stáli pred Bratislavou. Nevyhnutne sa opravovali škody spôsobené bojmi, no zároveň sa mesto pripravovalo aj na d’alšie potenciálne nebezpečenstvo. V 15. storočí posilnili obranu Laurinskej a Michalskej brány o barbakany. V tomto období vraj vzrástla nedôvera k českým remeselníkom a robotníkom pracujúcim na opevňovacích prácach. Domáci v nich videli možné ohrozenie. K vylepšovaniu opevnenia povzbudzoval aj král' Žigmund (Mencl-Menclová 1936, 58, 64-65; Fiala 1969, 10-11; HorváthLehotská-Pleva 1982, 53, 55, 85). Pri výskume Rybárskej brány bol na sokli na južnom čelnom múre zachytený rad opracovaných kvádrov s okosením. Na výstavbu použili lietavské vápence z lomov v Devínskej Novej Vsi. Na jednom z nich sa našla vyššie spomínaná väčšia kamenárska značka (Musilová 2011, 23-24).

Prestavba hradu Devín v 15. storočí bola realizovaná kamenármi pracujúcimi na stavbách v Bratislave. Týkala sa palácovej stavby vybudovanej pánmi z Gary a horného hradu. Pohyb kamenárov dokladajú kamenárske značky na Bratislavskom hrade a v Dóme sv. Martina. Analógie ku devínskym kamenárskym značkám sa našli aj v král'ovskom paláci v Budíne či v Dóme sv. Alžbety v Košiciach (Plachá-Hlavicová 2003, 72, 75, 78-79). Z publikovaných sme zhodu so značkami z Kaplnky sv. Jakuba však nenašli. Netypické značky boli nájdené v studni na nádvorí stredného hradu. Prvý raz ich spracoval vo výskumnej správe v roku 1971 A. Piffl $(2007,200$, 202-204; Pohaničová 2008, 29), neskôr ich publikovali V. Plachá a J. Hlavicová (2003, obr. 66, 81). Studňa bola vybudovaná za Garayovcov. Našlo sa v nej 24 typov značiek v celkovom počte 772. Zväčša sa v jednom rade vyskytuje len jeden typ značky, no v niektorých boli aj tri typy. Uvažuje sa o tom, že tieto značky mohli byt' montážnymi, ked’že sú jednoduchšie a sú úplne odlišné od značiek na architektonických článkoch hradu (Plachá-Hlavicová 2003, 79-80). Zaujímavým je nález depotu kamenných gúl' s priemerom $180 \mathrm{~mm}$, opatrených jednoduchou kamenárskou značkou v tvare kríža (Plachá-Hlavicová 2003, 69). Prvá zmienka o kostole v podhradskej osade Devín pochádza z roku 1307, pričom sa jej počiatky kladú už do 12. storočia. V prvej polovici 15. storočia patrilo mestečko Devín i hrad Garayovcom, ktorí dostali niekdajší královský majetok priamo od Žigmunda Luxemburského. Manželkou Mikuláša Garaya bola dcéra Hermana z Celje, Anna. V druhej polovici 15. storočia sa majitel'mi Devína stali grófi zo Sv. Jura a Pezinka. Majitelia panstva v priebehu 15. storočia pristavovali ku kostolu v obci svoje pohrebné kaplnky. Pri obnove boli zachytené aj kamenárske značky, ktoré sa však nezhodujú so skúmanými z Kaplnky sv. Jakuba v Bratislave (Johanidesová 1974, 7, 10-11; Plachá-Hlavicová 2003, 55, 65).

Prepojenie bratislavských kamenárov na Viedeň dokladajú analógie značiek v Katedrále sv. Štefana (Stefansdom). Najstaršie, no zriedkavé značky z tohto kostola sú datované do neskororománskeho obdobia (Horváth-Lehotská-Pleva 1982, 87-88; Rybáriková 1984, 138-139). 
Kamenári v Bratislave 15. storočia (tab. 2, 3)

V ranom stredoveku sa kamenári venovali predovšetkým výrobe žarnovov, osličiek a brúsikov. Stavební kamenári sa formovali ako dvorskí, no potulní remeselníci. V 9. storočí je viditel'ný cielavedomý výber stavebného materiálu a profesionálne postupy v dielňach pôsobiacich na hradiskách (Špiesz 1983, 19-20). Pracovnou náplňou kamenárov bolo od vrcholného stredoveku vytesávanie a osadzovanie kamenných blokov do miesta brán, dverí, okien a schodov. Okrem toho vyrábali aj kamenné gule a gul'ky do ručníc, hákovníc a diel. Často sa spájali s murármi, ktorí boli najdôležitejším stavebným remeslom. Spolu s nimi vytvárali na sklonku stredoveku spoločné cechy (Špiesz 1972, 273, 284; Krajčovičová 1972, 221; Rybáriková 1984, 24; Segeš 2010, 131-132). Predchodcami cechov murárov a kamenárov boli stavebné huty, ktoré sa v priebehu 12. storočia vyvinuli z kláštorných stavebných hút. Spočiatku pôsobili pri kapitulách, no popri „slobodných“ hutách sa v stredovekých mestách zdôrazňoval význam cechov (Ržiha 1989, 8-9, 11; Krajčovičová 1972, 218; Baur 1974, VII; Rybáriková 1984, 25). Členovia stavebných hút neboli viazaní na mestské cechy, ani na konkrétne miesto. Mali zvláštne privilégiá, potvrdzované a rozširované panovníkom. Huta si svoje vnútorné spory riešila vo svojom kruhu (Plachá-Hlavicová 2003, 70-71). Ich rozkvet nastal v období gotiky, kedy sa pri stavbe vel'kých katedrál zhromažd'ovali stavební špecialisti. Organizačne sa sformovali do dielenských spoločenstiev - hút (Legner 1978, 58; Binding 2000, 61). V Bratislave vznikla stavebná huta v 30. rokoch 15. storočia v súvislosti s prestavbou hradného paláca. Vtedy sem na pozvanie Žigmunda Luxemburského prichádzali odborníci z Čiech, Rakúska a Bavorska, no stavebných prác sa zúčastňovali aj domáci remeselníci (Krajčovičová 1972, 218).

Stavebné huty sa riadili presnými pravidlami, ktoré určovali pracovný čas, kompetencie a mzdy (Legner 1978, 58). Kým kamenár dosiahol najvyšší stupeň kvality, musel prejst' v Meissene, Čechách a Sliezsku štvor- a v ostatných častiach Európy až pätročným učením ako učeň. Pätročné učenie je zachytené aj $\mathrm{v}$ štatúte bratislavských kamenárov a murárov z roku 1552. Následne mal rozšírit' svoje vedomosti ako tovariš. Po vyučení dostal nový tovariš svoju značku, ktorá bola odvodená od koreňa huty. Počas povinných vandroviek sa ňou preukazoval, aby bol prijatý pod ochranu domácej stavebnej huty. Do huty mohol byt' prijatý najskôr po ročnej vandrovke. Pri prijímaní medzi majstrov musel dokázat' svoje zručnosti a splnit' d’alšie podmienky. Stavebné huty boli nadregionálne organizované. Kamenári z nemeckých hút neputovali len v nemeckom prostredí, ale v neskororománskom období sa zúčastňovali výstavby francúzskych katedrál, v období gotiky počas vandroviek navštevovali Čechy a Pol'sko. Predstaveným tova-

\begin{tabular}{|c|c|c|c|c|c|}
\hline Rok & Typ dokumentu & Kamenári & Murári & Poznámka & Literatúra \\
\hline $1434 / 1435$ & daňový súpis & 4 & 4 & & $\begin{array}{c}\text { Kováts 1900, 56-80; Hor- } \\
\text { váth-Lehotská-Pleva 1982, 65; } \\
\text { Rybáriková 1984, } 7\end{array}$ \\
\hline 1434 & $\begin{array}{l}\text { prestavba hradu-- } \\
\text { stavebný denník }\end{array}$ & \multicolumn{2}{|c|}{$\begin{array}{l}122 \text { kamenárov a murárov }+163 \\
\text { pomocných robotníkov }\end{array}$} & $\begin{array}{l}\text { pod vedením Konráda } \\
\text { z Erlingu, } 3 \text { palieri }\end{array}$ & Špiesz 2008, 180 \\
\hline 1439 & pozemková kniha & 4 & 4 & & $\begin{array}{l}\text { Krajčovičová 1972, 219; Rybári- } \\
\text { ková 1984, 8; Segeš 2010, } 132\end{array}$ \\
\hline $1452 / 1453$ & daňový súpis & $0 / 1$ & 6 & & $\begin{array}{l}\text { Krajčovičová 1972, 219; Rybári- } \\
\text { ková 1984, 8; Segeš 2010, 25-26 }\end{array}$ \\
\hline 1486 & kvitancia & 2 & & & $\begin{array}{c}\text { Krajčovičová } 1972,224 \text {; Rybári- } \\
\text { ková } 1984,10\end{array}$ \\
\hline 1488 & testament & & 2 & & Rybáriková 1984, 9 \\
\hline 1498 & pozemková kniha & 1 & & & Rybáriková 1984, 23 \\
\hline $1503 / 1504$ & daňový súpis & 1 & 7 & & $\begin{array}{c}\text { Krajčovičová } 1972,219 \text {; Rybári- } \\
\text { ková } 1984,8\end{array}$ \\
\hline 1524 & pozemková kniha & 1 & & & Rybáriková 1984, 23 \\
\hline
\end{tabular}

Tab. 2. Počty kamenárov zachytené v písomných prameňoch z 15. storočia v Bratislave.

Tab. 2. Anzahl der in den schriftlichen Quellen des 15. Jahrhunderts in Bratislava erfassten Steinmetze. 


\begin{tabular}{|c|c|c|c|c|}
\hline Rok & Kamenári & Murári & Poznámka & Literatúra \\
\hline $1379 ?$ & Fridel Steinprecher & & lámač kameňa pri veži Lugisland & Krajčovičová 1972, 220 \\
\hline 1382 & & Bernard & & Špiesz 1972, 218; Rybáriková 1984, 8 \\
\hline $1434 / 1435$ & Jeronimus & & ? kamenár & Kováts 1900,64 \\
\hline $1434 / 1435$ & Lapicida Chunrad & & kamenársky majster Konrád & Kováts 1900, 66; Fiala 1969, 15 \\
\hline $1434 / 1435$ & Parlir Chunz & & palier & Kováts 1900, 69 \\
\hline $1434 / 1435$ & Stainmetz Emerich & & & Kováts 1900, 77 \\
\hline $1434 / 1435$ & & Mawrer Chunz & & Kováts 1900, 67 \\
\hline $1434 / 1435$ & & Mawrer Lienhart & & Kováts 1900, 67 \\
\hline $1434 / 1435$ & & Schokkl Jorig & & Kováts 1900,74 \\
\hline $1434 / 1435$ & & Tanner Philip & & Kováts 1900, 77 \\
\hline 1434 & Konrád Lichtenfels z Erlingu & & $\begin{array}{c}\text { kamenársky majster, prestavba } \\
\text { Bratislavského hradu a Dómu } \\
\text { sv. Martina; vo výdavkoch mesta } \\
\text { 1434-1436 }\end{array}$ & $\begin{array}{l}\text { Fiala 1969, 15; Holčí-Štefanovičová } \\
\text { 1982, 48; Horváth-Lehotská-Pleva } \\
\text { 1982, 90; Plachá-Hlavicová 2003, } 72\end{array}$ \\
\hline 1434 & Prokop & & & Holčík-Štefanovičová 1982, 48 \\
\hline 1439 & Emmerich Steinmetz & & kameňolom na Vydrici & $\begin{array}{l}\text { Krajčovičová 1972, 219-220; Rybári- } \\
\quad \text { ková 1984, 8; Segeš 2010, } 132\end{array}$ \\
\hline 1439 & Lorentz Steinmetz & & & $\begin{array}{c}\text { Krajčovičová 1972, 219; Rybáriková } \\
\text { 1984, 8; Segeš 2010, } 132\end{array}$ \\
\hline 1439 & Pärtl Steinmetz & & & $\begin{array}{c}\text { Krajčovičová 1972, 219; Rybáriková } \\
\text { 1984, 8; Segeš 2010, } 132\end{array}$ \\
\hline 1439 & Ulrich Steinperger & & Steinmetz / Steinperger & $\begin{array}{c}\text { Krajčovičová 1972, 219; Rybáriková } \\
\text { 1984, 8; Segeš 2010, } 132\end{array}$ \\
\hline 1439 & & Hans Mawrer & & $\begin{array}{c}\text { Krajčovičová } 1972,219 ; \text { Rybáriková } \\
1984,8\end{array}$ \\
\hline 1439 & & Nycolae Mawrer & & $\begin{array}{c}\text { Krajčovičová } 1972,219 ; \text { Rybáriková } \\
1984,8\end{array}$ \\
\hline 1439 & & Brendl Mawrer & & $\begin{array}{c}\text { Krajčovičová } 1972,219 ; \text { Rybáriková } \\
1984,8\end{array}$ \\
\hline 1439 & & Lienhart Mawrer & & $\begin{array}{c}\text { Krajčovičová } 1972,219 ; \text { Rybáriková } \\
1984,8\end{array}$ \\
\hline $1440-1452$ & Henrich Stengel & & $\begin{array}{l}\text { majster, viedol práce na Dóme } \\
\text { sv. Martina }\end{array}$ & Horváth-Lehotská-Pleva 1982, 89 \\
\hline 1444 & 2 lámači kameňa & & $\begin{array}{l}\text { kameňolom pod Kostolom } \\
\text { sv. Martina }\end{array}$ & $\begin{array}{c}\text { Krajčovičová 1972, 220; Rybáriková } \\
1984,23\end{array}$ \\
\hline 1486 & cechmajster Paul & & & $\begin{array}{c}\text { Krajčovičová 1972, 224; Rybáriková } \\
1984,10\end{array}$ \\
\hline 1486 & majster Siebenbürger & & & $\begin{array}{c}\text { Krajčovičová } 1972,224 \text {; Rybáriková } \\
1984,10\end{array}$ \\
\hline 1486 & Hans Rorwegk / Rorbekh & & testament & $\begin{array}{c}\text { Krajčovičová } 1972,223 \text {; Segeš } 2010, \\
\text { 132-133 }\end{array}$ \\
\hline 1487 & & Paul Plueml & $\begin{array}{l}\text { zhotovil lešenie a okožoval mest- } \\
\text { ské múry - hradby }\end{array}$ & Krajčovičová 1972, 223 \\
\hline 1488 & & Wolfgang, majster & $\begin{array}{l}\text { testament, daroval } 2 \text { zlaté ka- } \\
\text { menárskemu cechu }\end{array}$ & $\begin{array}{c}\text { Krajčovičová 1972, 223; Rybáriková } \\
1984,9 ; \text { Segeš 2010, } 210\end{array}$ \\
\hline 1488 & & Paul Plueml & & $\begin{array}{c}\text { Krajčovičová 1972, 223; Rybáriková } \\
\text { 1984, 9; Segeš 2010, } 210\end{array}$ \\
\hline 1496 & & Paul Plueml & $\begin{array}{l}\text { kameňolom Seelendorf a pred } \\
\text { Vydrickou bránou, spravovanie } \\
\text { mestských hradieb }\end{array}$ & $\begin{array}{c}\text { Krajčovičová } 1972,220-221 \text { Rybári- } \\
\text { ková } 1984,23\end{array}$ \\
\hline 1498 & Rössler & & $\begin{array}{c}\text { lámač kameňa, kameňolom na } \\
\text { Vydrici }\end{array}$ & $\begin{array}{c}\text { Krajčovičová } 1972,220 \text {; Rybáriková } \\
1984,23\end{array}$ \\
\hline $1505-1507$ & majster Ulrich s tovarišmi & & $\begin{array}{c}\text { kameňolom v mestskej priekope } \\
\text { pod Kostolom sv. Martina }\end{array}$ & $\begin{array}{c}\text { Krajčovičová 1972, 220; Rybáriková } \\
1984,23\end{array}$ \\
\hline 1524 & Matej Pogner & & kameňolom na Vydrici & $\begin{array}{c}\text { Krajčovičová } 1972,220 \text {; Rybáriková } \\
1984,23\end{array}$ \\
\hline
\end{tabular}

Tab. 3. Kamenári pracujúci v 15. storočí v Bratislave.

Tab. 3. Im 15. Jahrhundert in Bratislava tätige Steinmetze. 
rišov bol palier, ktorý zastupoval majstra. Pri povýšení na majstra bola značka d’alej rozvinutá a slúžila ako jeho podpis na murive stavby. Majster sa mohol stat' vedúcim huty či stavby. Iba on mal právo vykonávat' remeslo vo vlastnej réžii, zamestnávat' tovarišov a vychovávat' učňov (Špiesz 1972, 17-18; 1983, 25-26; Baur 1974, 17, VII-VIII; Legner 1978, 60; Rybáriková 1984, 27, 31; Ržiha 1989, 12; Plachá-Hlavicová 2003, 70; Segeš 2010, 18, 134). Medzi remeselníkmi pracujúcimi s kameňom sa rozlišovali tri kategórie: murári, kamenári a lámači kameňa v kameňolomoch (Binding 2000, 61).

Najstarší poriadok hút z roku 1469 uvádza štyri huty s ich okruhmi pôsobnosti - Strassburg, Viedeň, Bern a Kolín. Majstrovi Lorentzovi Spanning, hlavnému majstrovi stavby v Katedrále sv. Štefana vo Viedni, prislúchajú oblasti Lambach, Štajersko, Merckhusen, Uhorsko a regióny od Dunaja nadol (Ržiha 1989,14). V prvej polovici 15. storočia mala v našom prostredí silný vplyv pražská kamenárska huta, ktorej kamenári hl’adali po smrti Václava IV. uplatnenie aj v Uhorsku, pod ochranou Žigmunda Luxemburského. Z karlovskej Prahy čerpala inšpiráciu i stavebná huta vo Viedni. Vymedzenie pôsobnosti Viedne v roku 1514 sa spomína v poriadku Regensburskej stavebnej huty na oblast' od Viedne po Dunaji smerom nadol,t. j. aj na územie Uhorska. Dokladom kontaktov je zhoda kamenárskych značiek v Katedrále sv. Štefana vo Viedni, na Bratislavskom hrade či v Dóme sv. Martina v Bratislave. Tento stav potvrdilo v rovnakom roku aj bazilejské zasadanie európskych hút, ktoré stanovilo výlučné a nadradené postavenie viedenskej huty v stredoeurópskom priestore. Uhorsko spadalo do jej kompetenčného okruhu (Baur 1974, VIII; Ržiha 1989, 12; Žáry-Bagin-Rusina-Toranová 1990, 39; Plachá-Hlavicová 2003, 71).

Za vlády Žigmunda Luxemburského nastal v Bratislave čulý stavebný ruch podnietený priamo záujmami panovníka. Na hrade fungovala kamenárska huta, ktorá sa podiel'ala nielen na výstavbe hradu, ale aj na prestavbe farského Kostola sv. Martina v podhradskom meste. Viedol ju majster Konrád Lichtenfels z Erlingu a na jeho práci boli viditel’né vplyvy parléřovskej dielne i budínskej stavebnej huty. Dvorská huta bola spravovaná král'ovským vrchným úradom a mala aj svojho pisára. V 30. rokoch 15. storočia mala až trojnásobne viac zamestnancov ako viedenská. Podriadenost' Viedni však dokladá fakt, že viedenskí majstri takmer celé 15. storočie rozhodovali o obsadení postu vedúceho majstra v Bratislave. Táto huta sa zameriavala hlavne na výstavbu svetských stavieb v meste a možno jej pripísat' účast' na prestavbe Vydrickej brány, niektorých meštianskych domov, mestskej fary na Kapitulskej ulici či výstavbe radnice (MenclMenclová 1936, 60, 70-74; Fiala 1969, 15; Horváth-Lehotská-Pleva 1982, 90; Žáry-BaginRusina-Toranová 1990, 59, 64). Viedenský základ mala spomínaná huta pri farskom Kostole sv. Martina, ktorej východiskom bola Katedrála sv. Štefana vo Viedni. Jej špecializáciou bola stavba sakrálnych stavieb. Okrem nich mohla v Bratislave fungovat' i staršia huta, ktorá pracovala na výstavbe kostola klarisiek a františkánov, t. j. na prelome 14. a 15. storočia (Mencl-Menclová 1936, 62, 64, 70).

V tabul'ke 2 a 3 uvádzame v prehl'adoch počty a mená kamenárov a murárov pracujúcich v 15. storočí v Bratislave. Najstarší záznam o murároch pochádza z roku 1382 (Krajčovičová 1972, 218). Podl'a archívnych správ v 15. storočí pracovalo v meste priemerne sedem až osem kamenárov a murárov. Je nutné si uvedomit', že v dokumentoch ako mestské knihy uvedený počet predstavuje počet majstrov pracujúcich v meste, ktorí mohli zamestnávat' d'alších tovarišov a učňov, teda reálny počet remeselníkov s touto špecializáciou v meste bol vyšší. Remeselníci v našich mestách patrili medzi stredné vrstvy meštianstva. To potvrdzuje aj zdanenie kamenárov a murárov v Bratislave v daňovom roku 1452/1453 na 1 až 5 zlatých (Krajčovičová 1972, 219; Špiesz 1972, 17; Rybáriková 1984, 8). Je nutné však povedat', že v roku 1435 zaplatil kamenársky majster Konrád pracujúci na hrade vínny desiatok 87 okovov. Bol v poradí tretí najvyšší platca tejto dane, teda vinice, ktoré vlastnil, museli byt' rozsiahle. Patril k majetným z vyššie postavených obyvatel'ov (Horváth-Lehotská-Pleva 1982, 72). V komorskej knihe Bratislavy z roku 1442 je medzi výdavkami mesta zachytený výdavok na službu - stavbu mosta - z 1. 9.1442 pre majstra Jána 10 zlatých florénov (Jurányi 2012, 39). Okrem neho sa spomína aj vyplatenie majstra 
Imricha s tovarišmi, lámačov kameňa a murárov pri Starom tábore v celkovej sume 20 libier ${ }^{6}$ a 4 denáre (Jurányi 2012, 50).

Najstaršia doložená písomnost' kamenárskeho cechu pochádza z roku 1486, kedy bola potvrdená kvitancia, potvrdenie o prebratí troch zlatých od bratislavského meštana a prísažného Petra Creucza, čím bola splatená pôžička vyššie uvedeného cechu. Sumu prebrali cechmajster Paul Steinmetz a majster Peter Siebenbürger, ktorí potvrdili listinu svojimi prsteňovými pečat’ami (Krajčovičová 1972, 224; Rybáriková 1984, 10). V roku 1486 vydalo mesto predpis, ktorý stanovil mzdu pre murárov a kamenárov a zakazoval zamestnávat' mimobratislavských remeselníkov (Horváth-Lehotská-Pleva 1982, 66).

Zmienky o kamenárskom cechu nachádzame aj v testamentoch bratislavských meštanov. Príkladom je testament Hansa Rorwegka / Rorbekha (28. 4. 1486), v ktorom menovaný odkázal kamenárskemu cechu 5 talentov (denárov), t. j. 12 uhorských zlatých (Krajčovičová 1972, 223; Rybáriková 1984, 9; Segeš 2010, 132-133). Murár Wolfgang v roku 1488 daroval cechu kamenárov 2 zlaté a pri spisovaní testamentu bol prítomný aj iný murár, Paul Plueml (Krajčovičová 1972, 223; Rybáriková 1984, 9).

Už v 40. rokoch 15. storočia žiadali tesárski a murárski tovariši vyššie mzdy (HorváthLehotská-Pleva 1982, 63). V roku 1497 mesto upravilo mzdy pre murárov a kamenárov. V lete bola stanovená denná mzda pre majstrov na 24 denárov, pre tovarišov na 20 denárov a v zime boli majstri platení 20 denármi na deň a tovariši 16 (Krajčovičová 1972, 223; Rybáriková 1984, 9-10). O pár rokov neskôr, v roku 1512, mesto opät’ stanovilo výšku mzdy pre murárov a tesárov a to tak, že majstri v lete dostávali 9 grajciarov a tovariši 8 grajciarov. V zime bola denná mzda majstra 8 grajciarov a tovariša 7 grajciarov. V prípade, že mali zabezpečenú stravu, raňajky a olovrant, mzda bola nižšia. V zime to bolo 6 grajciarov na deň pre majstra a 5 pre tovariša (Krajčovičová 1972, 223-224; Rybáriková 1984, 10).

V našom prostredí sa presadil v Európe najrozšírenejší typ cechovníctva, nemecké, ktorý so sebou prinášali kolonisti z uvedených regiónov. Jeho charakteristickou črtou bolo povinné členstvo v nich pre všetkých majstrov. Prvé cechy u nás sa formovali ako bratstvá jednotlivých svätcov (Špiesz 1972, 33-34). Prvý štatút kamenárskeho cechu, ktorý spájal kamenárov a murárov (Steinmetzen und Mauer), udelila mestská rada v Bratislave 7. februára 1552. Bol spísaný hlavne kvôli nezhodám medzi domácimi a talianskymi remeselníkmi (Krajčovičová 1972, 225; Špiesz 1978, 23; Rybáriková 1984, 10-11).

V druhej polovici 15. storočia sa $\mathrm{v}$ mestských knihách vyskytujú výdavky na lámačov kameňa a ich pomocníkov. Kameňolomy zvyšovali príjmy mesta (Krajčovičová 1972, 220). V stredovekej Bratislave a jej okolí existovalo niekol'ko kameňolomov. Najstarší bol na hradnom vrchu, pod vežou Lugisland. Prvá zmienka o ňom je z roku 1379 a t’ažilo sa v ňom do roku 1550. Druhý kameňolom fungoval pri Vodnej veži (v prameňoch uvádzaný aj ako na Vydrici), ktorý sa spomína od roku 1439 do prvej polovice 16. storočia. Je však možné, že bol otvorený v období výstavby Vodnej veže, teda v roku 1294. Tretím miestom tažby kameňa bola mestská priekopa pod Kostolom sv. Martina. V kameňolome sa pracovalo v 15. aj 16. storočí. Aj on mohol byt' otvorený skôr, v čase úpravy priekopy pred západnou fasádou farského Kostola sv. Martina (1401). Zmienky o kameňolome v Selendorfe (Horná Mlynská Dolina) pochádzajú z konca 15. storočia. Okrem uvedených fungovali aj kameňolomy v lokalite Feundberg (Hlboká cesta) a v Lamači (Fiala 1969, 16-17; Krajčovičová 1972, 220-221; Rybáriková 1984, 23; Horváth 1990, 257). V spomínaných kameňolomoch sa t’ažila žula na stavebný lomový kameň. Okrem nich sa v stredoveku t’ažil kameň aj v areáli Bratislavského hradu, no pravdepodobne len pre potreby výstavby na hradnom kopci.

Pri kameňolomoch fungovali kamenárske huty (Krajčovičová 1972, 221; Rybáriková 1984, 24). Jedna z nich sa spomína oproti Kostolu sv. Martina v roku 1440 a druhá pri Kostole sv. Michala v roku 1456 (Krajčovičová 1972, 221; Rybáriková 1984, 24).

61 libra = 240 denárov (Jurányi 2012, 56). 
V románskom období používali stavitelia hlavne miestny kameň, no dekoratívne prvky vyrábali z mäkších vápencov, pieskovcov alebo mramorov. Tým, že sa v gotike začali stavby zvyšovat', bolo potrebné dobre poznat' vlastnosti kameňa, jeho pevnost', pružnost' i nosnost'. Preferované boli nad’alej blízke zdroje alebo zakladanie stavieb priamo na skalu (Kukal-Malina-Malinová-Tesařová 1989, 188, 190-191). V českom královstve bol kameňom vrcholnej gotiky pieskovec, na našom území sa na stavbu používali predovšetkým miestne zdroje (Kužvart 1990, 178-179). V stredovekej Bratislave sa okrem tunajšieho kameňa používal aj dovezený. V archívnych materiáloch je zachytený dovoz tvrdšej žuly z rakúskych regiónov na priečelia domov. Domáci kameň bolo možné použit' na základy, reguláciu dunajského nábrežia a hrádze, dláždenie ulíc i námestí. Rozdrobená žula zmiešaná s vápnom sa používala na výstavbu hradieb. Na dláždenie mesta boli pozývaní kamenári z Viedne alebo Šopronu. Až v roku 1496 zamestnalo mesto svojich dláždičov s týždennou mzdou jeden dukát. Ked’že išlo o pomerne vel'kú sumu, je pravdepodobné, že z nej boli vyplácané aj mzdy pomocníkov a náklady na materiál. Z obdobia prestavby bratislavského hradu za vlády Žigmunda Luxemburského sa zachoval stavebný denník, v ktorom sa spomína kúpa kameňa $\mathrm{v}$ Mannsdorfe. $\mathrm{Z}$ tohto kameňolomu dodávali do Bratislavy vápencové bloky, ktoré priamo tam chodil vyberat' a kupovat' sám majster Konrád, zodpovedný za prestavbu hradu. Archívne pramene rovnako dokladajú dovoz a platbu za kameň z Hainburgu. V rokoch 1496 a 1503 zaplatilo mesto majstrovi Osvaldovi za konzoly a kvádrový kameň 29 zlatých a 4 šilingy (Fiala 1969, 17; Krajčovičová 1972, 221; Horváth-Lehotská-Pleva 1982, 66; Rybáriková 1984, 23-24; Špiesz 2008, 103-104).

V kameňolomoch pripravovali lámači a nádenníci materiál do tvaru kvádrov, ktoré sa ako polotovar prepravovali d'alej na miesto stavby. Okrem toho tu vyhotovovali bosované kamene a snád' aj rímsy a časti oblúčkového vlysu, teda skôr častí, pri ktorých sa nekládol dôraz na presnost' (Fiala 1969, 17).

\section{Petrografické vyhodnotenie vzoriek z Kaplnky sv. Jakuba v Bratislave}

Na spracovanie bolo odobraných pät' vzoriek pochádzajúcich z Kaplnky sv. Jakuba v Bratislave. Horniny múrov a kamenných článkov boli zdokumentované fotograficky. Vzorky boli opísané z makroskopického pozorovania a pomocou lupy zväčšujúcej $30 \times$. Zo vzoriek boli vyhotovené výbrusy na mikroskopickú analýzu. Na základe petrografie boli dané horniny zaradené do geologickej jednotky, v ktorej pravdepodobne vznikali. Na základe nich a analógie s inými pamiatkami bol vytypovaný pravdepodobný zdroj kamenného materiálu. Skúmaný bol i spôsob opracovania povrchu kamenárskych výrobkov.

\section{Vzorka č. 1 - Slabo opracovaný kamenný blok, 13. storočie (obr. 6a)}

Hornina je na prvý pohl’ad žula, ktorá sa kvôli tvrdosti a krehkosti nedá dobre opracovávat'. Žulový blok má dížku ca $50 \mathrm{~cm}$. V mikroskope vidno, že hornina je strednozrnná, zložená z kremeňa (46\%), draselných živcov (40\%), ktoré sú čiastočne sericitizované a kaolinizované. $\mathrm{Z}$ draselných živcov sa dali identifikovat' ortoklas, málo výrazný pertit a mikroklín. V hornine sú aj plagioklasy (10\%) a ich špeciálny typ myrmekit. Zvyšok (4\%) predstavujú sl’udy (biotit a muskovit) a iné minerály. Na základe zloženia môžeme horninu nazvat' syenogranit. Podl’a prítomnosti aplitovej štruktúry a malej vel'kosti zín horninu môžeme pomenovat' ako žilný ekvivalent granitu, čiže aplit. Podobné horniny sa nachádzajú na hradnom vrchu a všetkých vyvýšených miestach v Starom meste.

\section{Vzorka č. 2-Kamenný článok, 13. storočie}

Článok dlhý ca $25 \mathrm{~cm}$ vyzerá byt' na prvý pohl’ad vytesaný z pieskovca. Vzorka je zložená zo strednozrnného (až jemnozrnného) pieskovca s maximálnymi zrnami do 1, ojedinele $6 \mathrm{~mm}$. V mikroskope vidno, že hornina je zložená zo štyroch druhov čiastočiek: fosílie (21 \%), karbonáty (13\%), siliciklastické zrná (7\%) a intraklasty či agregáty zón (7\%). Medzi zrnami je kalcitový 
tmel (33\%), ktorý môže byt’ čiastočne z rekryštalizovaných fosílií alebo karbonátov, základná hmota (11\%), čo môže byt' čiastočne organická siet' a póry $(8 \%)$.

Z fosílií sú najviac zastúpené červené riasy, menej echinodermáta (úlomky ježoviek), organické obaly zín, foraminifery (dierkavce), machovky a rúrky červov. Vo výbruse je hodne karbonátov, najviac sparitov (dolomity, rekryštalizované vápence, aj usmernené). Ďalšou zložkou horniny sú siliciklastické zrná ako sú porfyroidy a kremenné zrná. Na základe zloženia môžeme horninu nazvat' hybridným pieskovcom (Zuffa 1980). Geologicky je to typ litavského vápenca bádenského veku (Baráth et al. 1994). Podobný sa nachádza v okolí Devína. Najpravdepodobnejšou lokalitou je vel'ký historický kameňolom na JZ svahu Devínskej Kobyly. Zložením podobné horniny sa používali v 13. až 15. storočí v Bratislave a Devíne, napr. na Bratislavskom hrade, Katedrále sv. Martina alebo v Devínskom kostole.

\section{Vzorka č. 3 - Kamenný článok z vrchnej rímsy, 15. storočie (obr. 6b)}

Vzorka je zložená z jemnozrnného až strednozrnného pieskovca s maximálnymi zrnami do 1, ojedinele $2 \mathrm{~mm}$. V mikroskope vidno, že hornina je zložená zo štyroch druhov čiastočiek: fosílie (28\%), siliciklastické zrná $(17 \%)$, karbonáty $(9 \%)$ a intraklasty či agregáty zŕn $(3 \%)$. Medzi zrnami je kalcitový tmel (14\%), základná hmota (25\%), ktorá môže byt' čiastočne z rias a póry $(4 \%)$.

Z fosílií sú najviac zastúpené červené riasy, organické obaly zín a echinodermáta. Vo výbruse je hodne siliciklastických zŕn, ako sú kremenné zrná, porfyroidy a bridlice. Z karbonátov je najviac sparitov (dolomity, rekryštalizované vápence, aj usmernené). Na základe zloženia môžeme horninu nazvat' hybridným pieskovcom. Geologicky je to typ litavského vápenca bádenského veku. Lokalizácia pôvodu kameňa je podobná ako u predošlej vzorky.

\section{Vzorka č. 4-Dlhý kamenný článok, 13. storočie (obr. 6c)}

Článok dlhý ca $80 \mathrm{~cm}$ vyzerá byt' na prvý pohl’ad vytesaný z pieskovca. Vzorka je zložená z hrubozrnného ,pieskovca“ s maximálnymi zrnami do $3 \mathrm{~mm}$. Obsahuje aj strednozrnnú a jemnozrnnú frakciu. V mikroskope vidno, že hornina je zložená zo štyroch druhov čiastočiek: prevažujú fosílie (45\%), menej je intraklastov alebo agregátov zín (9\%), siliciklastických zŕn (4\%) a karbonátov (3\%). Medzi zrnami je kalcitový tmel (19\%), základná hmota (16\%), ktorá môže byt' čiastočne z rias a póry $(4 \%)$.

$\mathrm{Z}$ fosílií sú najviac zastúpené červené riasy, menej echinodermáta, machovky, foraminifery, lastúrniky a rúrky červov. Vo výbruse sú i karbonáty, najviac sparity (dolomity, rekryštalizované vápence). Ďalšou zložkou horniny sú siliciklastické zrná, ako sú kremenné zrná a porfyroidy. Na základe zloženia môžeme horninu nazvat' organogénnym vápencom. Geologicky je to typ litavského vápenca bádenského veku. Podobný sa nachádza v okolí Devína, pravdepodobne na lokalite Metzen (Merice). Zložením podobné horniny sa použili napr. v predchodcoch Katedrály sv. Martina - zistené pri archeologickom výskume (Štefanovičová 2004).

\section{Vzorka č. 5 - Kamenný článok zo zásypu ossária, 13. storočie (obr. 6d)}

Vzorka je zložená z hrubozrnného ,pieskovca“ s maximálnymi zrnami do 1,5 mm. Obsahuje aj hojnú strednozrnnú a jemnozrnnú frakciu. V mikroskope vidno, že hornina je zložená z troch druhov čiastočiek: prevažujú fosílie (57\%), menej je intraklastov alebo agregátov zín $(16 \%)$ a siliciklastických zŕn (9\%). Medzi zrnami je kalcitový tmel $(12 \%)$ a póry $(6 \%)$.

$\mathrm{Z}$ fosílií sú najviac zastúpené červené riasy, vel’mi často oválne hl’úzky (47\%), menej lastúrniky (hojné ustrice), machovky, echinodermáta a vel'ké foraminifery. Vo výbruse sú i siliciklastické zrná, ako sú kremenné zrná, niektoré so sericitom. Na základe zloženia môžeme horninu nazvat' riasovým vápencom. Geologicky je to typ litavského vápenca bádenského veku. Podobný sa nachádza na severe Litavských vrchov. Hojne bol použitý v Gerulate a v iných rímskych pamiatkach. Predpokladáme jeho sekundárne použitie. 

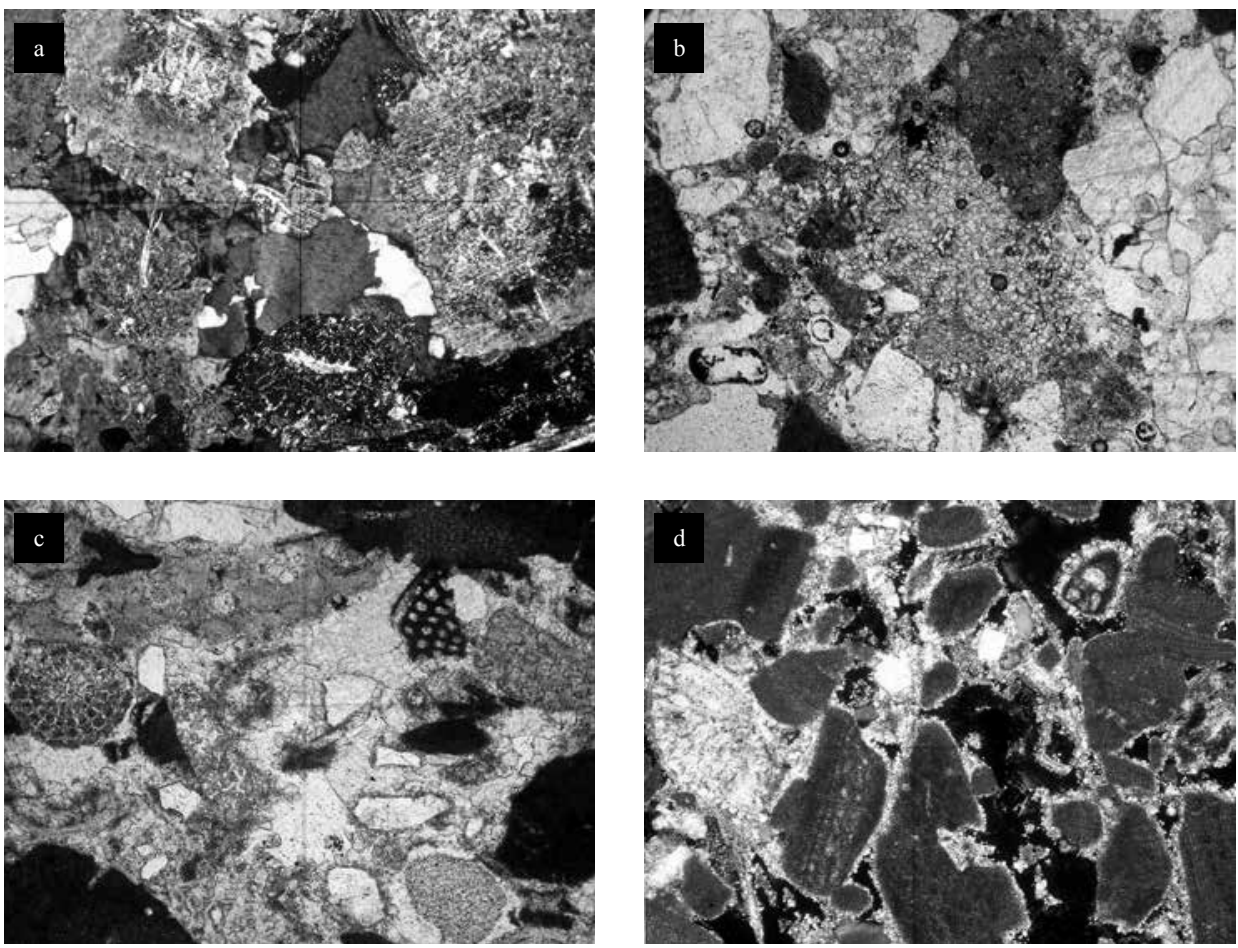

Obr. 6. Výbrusy kameňov pozorované pod mikroskopom (šírka zorného pol’a $2 \mathrm{~mm}$ ). a - vzorka č. 1 , 13. storočie, aplit s viditel’nými živcami, kremeňom a muskovitom v polarizovanom svetle; b - vzorka č. 3,15 . storočie, hybridný pieskovec s obsahom karbonátov, kremeňa a rias; c - vzorka č. 4, 13. storočie, organogénny vápenec s identifikovanými riasovými hl'úzkami, úlomkami ježoviek, machovkou, dierkavcom a kúskami kremeňa; d - vzorka č. 5, 13. storočie, riasový vápenec s prevahou riasových hl'úzok, s úlomkami kremeňa a s vel'kým dierkavcom (v polarizovanom svetle). Foto D. Pivko.

Abb. 6. Dünnschliffe der Gesteine unter dem Mikroskop (Blickfeldbreite $2 \mathrm{~mm}$ ). a - Probe Nr. 1, 13. Jhdt., Aplit mit sichtbaren Feldspaten, mit Quarz und Muskovit in polarisiertem Licht; b - Probe Nr. 3, 15. Jhdt., hybrider Sandstein mit Gehalt an Carbonaten, Quarz und Kalkalgen; c - Probe Nr. 4, 13. Jhdt., organogener Kalkstein mit identifizierten Kalkalgen, Seeigelfragmenten, mit Moostierchen, Foraminiferen und Quarzstückchen; d - Probe Nr. 5, 13. Jhdt., Algenkalkstein mit Übergewicht an Kalkalgen, mit Quarzfragmenten und großer Foraminifere, (in polarisiertem Licht). Foto D. Pivko.

\section{Opracovanie kameňa}

Na kamenných kvádroch a architektonických článkoch z 13. storočia (obr. 7a) vidno rovnobežné stopy po sekere vedené kolmo i šikmo na povrch, miestami meniace smer, všeobecne idúce šikmo k okraju kvádrov a článkov. Tento typ opracovania je bežný pre toto obdobie (Pivko 2012). Śírka rovného ostria obojstrannej sekery bola viac ako $5 \mathrm{~cm}$. Kvádre opracované v 15 . storočí (obr. 7b) majú husté ryhy idúce rovnobežne s okrajom. Š́rka stopy je však len ca 3 až $4 \mathrm{~cm}$, čo sa robilo v tom období úzkou obojstrannou sekerou. Pohl'adové strany, napr. viditel’né časti klenbových rebier, ríms sú opracované vel’mi jemne, skryté časti sú opracovane dorovna, aby články pasovali k sebe, poriadok rýh však nie je taký presný, často vidno i diery po prvotnom opracovaní špicákom alebo prírodné dutiny v kameni.

Na stavbu Kaplnky Sv. Jakuba používali lomový kameň, ktorý pochádza zo žulových kameňolomov v blízkosti dnešného centra Bratislavy. Na jemne opracované výrobky v 13. storočí využívali ešte materiál z rozoberaných rímskych stavieb. Poukazuje na to článok z materiálu zo severu Litavských vrchov, aký sa v stredoveku nevyužíval (Pivko 2014). Rímsky materiál v období stavebného boomu v 13. storočí nestačil, tak začali t'ažit' neogénne pieskovce až vápence 
na svahoch Devínskej Kobyly nad Devínom. V 15. storočí pokračovali v t’ažbe v dodnes zachovanom kameňolome vysoko na svahu severovýchodne od Devína (Pivko 2011). Zo skúmaných vzoriek sme nezistili materiál z Hainburských vrchov. Podl’a petrografických výskumov sa však od 13. storočia bežne používal (Pivko 2010; 2012; 2012a).
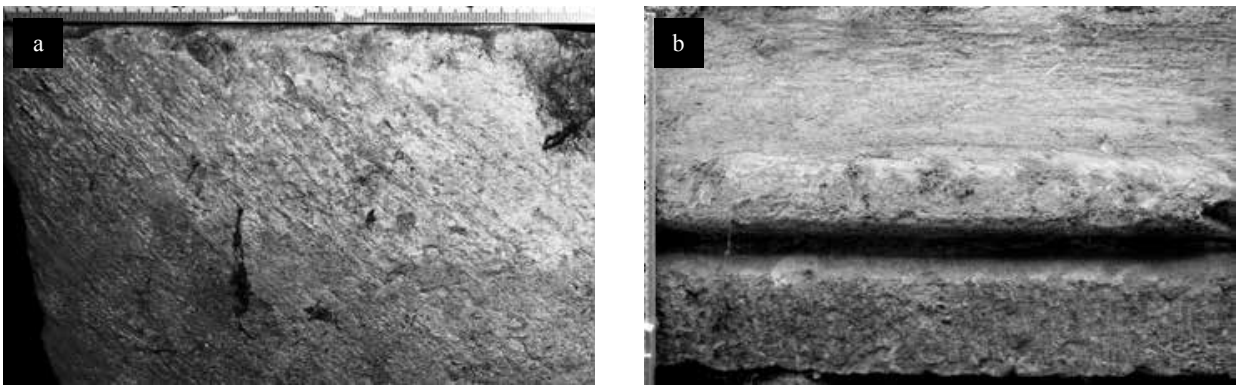

Obr. 7. Opracovanie povrchu kamenných článkov. a - obojstrannou sekerou v 13. storočí s rovnobežnými údermi idúcimi šikmo k okraju článku, pričom na ploche sa mení sklon úderov; b - jemné rovnobežné údery úzkou obojstrannou sekerou v 15. storočí. Foto D. Pivko.

Abb. 7. Oberflächenbehandlung der Steinmetzelemente. a - mit einer Doppelaxt im 13. Jhdt. mit parallelen, schräg zum Rand des Elementes geführten Hieben bei unterschiedlichen Ansatzwinkeln; b - leicht parallele Hiebe mit schmaler Doppelaxt im 15. Jhdt. Foto D. Pivko.

\begin{tabular}{|c|c|c|c|c|}
\hline kameňolom & 1. zmienka & ukončené práce & huta - 1. zmienka & literatúra \\
\hline pri veži Lugisland & 1379 & 1550 & & $\begin{array}{l}\text { Fiala 1969, 16; Krajčovičová 1972, 220; Rybáriková } \\
\qquad 1984,23\end{array}$ \\
\hline pri Vodnej veži & 1439 & 1524 & Paul Pleuml & $\begin{array}{l}\text { Fiala } 1969,16 ; \text { Krajčovičová 1972, 220-221; Rybári- } \\
\text { ková 1984, 23-24 }\end{array}$ \\
\hline pri Kostole sv. Martina & 1444 & 1507 & 1440 & $\begin{array}{c}\text { Fiala 1969, 16-17; Krajčovičová 1972, 220-221; } \\
\text { Rybáriková 1984, 23-24 }\end{array}$ \\
\hline pri Kostole sv. Michala & & & 1456 & Krajčovičová 1972, 221; Rybáriková 1984, 24 \\
\hline Selendorf & 1496 & & & Krajčovičová 1972, 220-221; Rybáriková 1984, 23 \\
\hline
\end{tabular}

Tab. 4. Kameňolomy a huty prevádzkované v 15. storočí v Bratislave.

Tab. 4. Im 15. Jahrhundert in Bratislava aufgeführte Steinbrüche und Bauhütten.

\section{Záver}

Pätnáste storočie zanechalo v Bratislave a okolí výrazný horizont gotických stavieb. Prvú polovicu 15. storočia môžeme dat' do súvisu so záujmom Žigmunda Luxemburského o Bratislavu ako takú, o zvýšenie jej obranyschopnosti v období husitských výbojov či snahu postavit' královskú rezidenciu na Bratislavskom hrade. Okrem toho bola podporovaná aj prestavba sakrálnych stavieb, ktoré sa rozširovali pre potreby farníkov a mali poukázat' na ich štedrost'. Do tohto obdobia spadajú gotické prestavby na Svätovavrineckom predmestí, tak farského Kostola sv. Vavrinca, ako aj obe prestavby Kaplnky sv. Jakuba. Práve výskum cintorínovej kaplnky priniesol zaujímavé nálezy kamenárskych značiek. Rozdelili sme ich do troch kategórií - autorské, vel'ké (majstrovské?) a osadzovacie. Ich analýza nás vedie k záverom, že na kaplnke pracovalo minimálne jedenást' kamenárov (značky č. 1-3 môžeme chápat' ako totožné, č. 7-8 by mohli označovat' rovnako jedného kamenára, značka č. 11 je otázna). Bolo však možné zhodnotit' len priestor severnej a západnej strany kaplnky, zvyšná čast' jej obvodových murív je bud' nepreskúmaná alebo nedostupná.

Analógie ku značkám dokladajú väzby kamenárov na oblast’ Bratislavy, huty pracujúce na prestavbe farského Kostola sv. Martina a hradu, no aj na ned’alekú Viedeň (Stefansdom, kostol minoritov), ktorá ovplyvňovala celý stredoeurópsky priestor. Zaujímavé sú podobnosti so znač- 
kami v Dóme sv. Alžbety v Košiciach, Katedrále sv. Víta a Hradu v Prahe či so vzdialeným dómom v Regensburgu.

Analýza materiálu (vzorka č. 3) kamenných článkov potvrdila, že použitý pieskovec bol používaný aj na ostatných súčasných stavbách v Bratislave a pochádza z domácich zdrojov (lomy v Bratislave, Devíne). Staršie kamenárske značky tvoria zároveň kategóriu osadzovacích a našli sa v sekundárnych polohách (zamurované v obvodovom murive a v zásype kostnice). Na základe petrografickej analýzy (vzorka č. 5) je možné predpokladat', že v uvedenom období sa na stavbu využívali aj kamene zo starších, antických stavieb, niekedy stojacich v priestore Bratislavy a okolia.

\section{Pramene a literatúra}

AMB: Archívhl. mesta SR Bratislava, Zbierka listín a listov, inv. č. 950 - listina z 26. 3. 1422.

BARÁTH, I.-NAGY, A.-KOVÁČ, M., 1994: Sandberské vrstvy - vrchnobádenské marginálne sedimenty východného okraja Viedenskej panvy. Geol. práce, Správy 99, 59-66.

BAUR, K., 1974: Der Stein in Architektur und Plastik (Eine vergleichende Stilkunde). München.

BINDING, G., 2000: Was ist Gotik? Eine Analyse der gotischen Kirchen in Frankreich, England und Deutschland 1140-1350. Darmstadt.

FIALA, A., 1969: Gotická architektúra Bratislavského hradu, Zborník Filozofickej fakulty Univerzity Komenského: Historica 20, 7-52.

- 2001: Odborný posudok ku kamenárskej značke z predbránia Rybárskej brány. Bratislava.

- 2008: Profesor Piffl a jeho bádatel'ská činnost'. In: Profesor Alfréd Piffl. Zborník príspevkov z medzinárodnej konferencie pri príležitosti storočnice narodenia, Bratislava, 13. júna 2007, 33-46. Bratislava.

FIALA, A.-SEMANKO, A., 1993: K architektúre gotického paláca Bratislavského hradu, Pamiatky a múzeá 3, 21-23.

HAVLÍK, M.-SABADOŠOVÁ, E., 2012: Korunná veža Bratislavského hradu - stavebný vývoj, Monumentorum Tutela - Ochrana pamiatok 24, 167-177.

HOLČÍK, Š.-ŠTEFANOVIČOVÁ, T., 1982: Bratislavský hrad. Bratislava.

HOŠŠO, J.-LESÁK, B., 1996: Archeologický výskum predrománskej rotundy a karnera zaniknutej osady sv. Vavrinca v Bratislave - Die archäologische Erforschung der vorromanischen Rotunde und des Karners in der untergegangenen Siedlung des H1. Vavrinec/Laurenz in Bratislava, AH 21, 241-251.

HORVÁTH, V., 1990: Bratislavský topografický lexikon. Bratislava.

- 1991: Bratislavské mestské privilégium. Ondrej III. - 2. december 1291. Bratislava.

HORVÁTH, V.-LEHOTSKÁ, D.-PLEVA, J., edd., 1982: Dejiny Bratislavy. Bratislava.

HUDÁK, J., 1984: Patrocíniá na Slovensku. Súpis a historický vývin. Bratislava.

JOHANIDESOVÁ, M., 1974: Stavebný vývoj devínskeho kostola. Bratislava.

JUDÁK, V.-POLÁČIK, Š., 2009: Katalóg patrocínií na Slovensku. Bratislava.

JURÁNYI, L., 2012: Rozbor komornej knihy mesta Bratislavy z roku 1442. Bakalárska práca, Katedra archívnictva a pomocných vied historických, Univerzita Komenského v Bratislave.

KOVÁTS, F., 1900: Városi adózás a középkorban. Pozsony szab. kir. Város levéltárának anyaga nyomán. Poszony.

KRAJČOVIČOVÁ, K., 1972: Cech murárov a kamenárov v Bratislave. In: Bratislava. Spisy Mestského múzea v Bratislave, zv. VII, 217-247. Bratislava.

KUKAL, Z.-MALINA, J.-MALINOVÁ, R.-TESAŘOVÁ, H., 1989: Člověk a kámen. Praha.

KUŽVART, M., 1990: Kámen ve službách civilizace. Praha.

LEGNER, A., 1978: Die Parler und der schöne Stil 1350-1400. Europäische Kunst unter den Luxembuegern. Köln.

MASUCH, H., 1998: Steinmetzzeichnen. Eine Einführung zu einer systematischen Erfassung, Niedersachsiche Denkmalpflege 14, 82-95.

MELZER, G.-REICHINGER, E., 1990: Die mittelalterliche Kirche Maria Himmelfahrt in Winzendorf, VB Wiener Neustadt, NÖ, Archaeologia austriaca 74, 131-236.

MENCL, V., 1935: Výkop farního kostela sv. Vavřince v Bratislavě, Bratislava 9, 465-467.

MENCL, V.-MENCLOVÁ, D., 1936: Bratislava, stavební obraz města a hradu. Praha.

MUSILOVÁ, M., 2011: Gotické predbránie Rybárskej brány v Bratislave, jeho objav a prezentácia, Bratislava - Zborník Múzea mesta Bratislavy XXIII, 19-33. 
NEUMANN, M., 2014: Kostol sv. Jakuba staršieho v Trnave. Príspevok k prítomnosti Valónov na území mesta v stredoveku, Pamiatky Trnavy a Trnavského kraja 17, 15-20.

PAULUSOVÁ, S.-GOJDIČ, I., 1977: Karner sv. Michala v Trenčíne (prvá etapa výskumov), Pamiatky a príroda, č. 3, 14-17.

PIFFL, A., 2007: Zápas o Bratislavský hrad. Denník 1948-1972. Bratislava.

PIVKO, D., 2010: Významné horniny používané ako opracované kamene v historických pamiatkach Slovenska, Mineralia Slovaca 42, č. 2, 241-248.

- 2011: Historický kameňolom litavských vápencov v Devíne pri Bratislave - Historischer Steinbruch Litauer Kalksteine in Devín bei Bratislava. In: Forum urbes medii aevi VI - Surovinová základna a její využití ve středověkém městě, 204-211. Brno.

- 2012: Stavebný a dekoračný kameň a jeho opracovanie na stredovekom Slovensku - Stein und seine Verarbeitung in der Slowakei des Mittelalters, AH 37, 609-628.

- 2012a: Zdroje kamenného materiálu na historické stavby na hradnom vrchu v Bratislave, Monumentorum Tutela - Ochrana pamiatok 24, 179-196.

- 2014: Rímske opracované kamene na Bratislavskom hradnom kopci a v širšom okolí, sekundárne využívanie v stredoveku. In: Bratislavský hrad dejiny, výskum a obnova (Musilová, M.-Bárta, P.-Herucová, A., edd.), 261-271. Bratislava.

PLACHÁ, V.-HLAVICOVÁ, J., 2003: Devín - slávny svedok dávnej minulosti. Bratislava.

POHANIČOVÁ, J., 2008: Ked' archívy rozprávajú ... alebo Architekt Alfréd Piffl - mnohodimenzionálna komplexnost'. In: Profesor Alfréd Piffl. Zborník príspevkov z medzinárodnej konferencie pri príležitosti storočnice narodenia, Bratislava, 13. júna 2007, 10-29. Bratislava.

RUPPELDTOVÁ, S., 2006: Púte v duchovnom a materiálnom odkaze Európy. Vzt’ah strednej Európy a Santiaga de Compostela. Diplomová práca, Katedra archeológie, Filozofická fakulta Univerzity Komenského, Bratislava.

RYBÁRIKOVÁ, M., 1984: K otázke kamenárskych značiek v Bratislave. Diplomová práca, Katedra archeológie, Filozofická fakulta Univerzity Komenského, Bratislava.

RYBÁRIKOVÁ-SERDAHELY, M., 1989: Stredoveké kamenárske značky z Dómu sv. Martina v Bratislave, ZbSNM LXXXIII - História 29, 109-123.

RŽIHA, F., 1989: Studien über Steinmetz-Zeichnen. Leipzig.

SEGEŠ, V., 2010: Remeslá a cechy v starom Prešporku. Bratislava.

SLIVKA, M., 2013: Uctievanie svätých na Slovensku. K problematike výskumu patrocínií. In: Slivka, M., Pohlady do stredovekých dejín Slovenska. Res intrincesus lectae, 93-134. Martin.

ŠPIESZ, A., 1972: Remeslo na Slovensku v období existencie cechov. Bratislava.

- 1978: Štatúty bratislavských cechov. Bratislava.

- 1983: Remeslá, cechy a manufaktúry na Slovensku. Martin.

- 2008: Bratislava v stredoveku. Bratislava.

ŠTEFANOVIČOVÁ, T., 2004: Výskum Dómu sv. Martina v Bratislave. In: Dóm sv. Martina v Bratislave. Archeologický výskum 2002-2003 (Štefanovičová, T., ed.), 9-41. Bratislava.

ZUFFA, G. G., 1980: Hybrid arenites: their composition and classification, Journal of Sedimentary petrology 50, 21-30.

ŽÁRY, J.-BAGIN, A.-RUSINA, I.-TORANOVÁ, E., 1990: Dóm sv. Martina v Bratislave. Bratislava.

\section{Zusammenfassung}

\section{Steinmetzzeichen aus der St. Jakobskapelle in Bratislava}

In der hier vorgelegten Studie greifen wir die an der Friedhofskapelle in der Laurentius-Vorstadt von Bratislava gemachten Funde wieder auf. Zentrum unseres Interesses war die in das 15. Jahrhundert datierte dritte und vierte Bauphase der Kapelle, d.h. in die Zeit der Gotik, die in Bratislava und Umgebung einen ausgeprägten Horizont an Bauten hinterlassen hat. Den großen Ausbau kann man mit Sigismunds von Luxemburg Interesse, die Verteidigungsfähigkeit von Bratislava während den Hussitenkriegen zu verbessern und mit dem Bestreben in Verbindung bringen, auf der Burg von Bratislava eine Königsresidenz zu errichten. Gleichzeitig wurde auch der Umbau von Sakralbauten gefördert, die entsprechend den Bedürfnissen der Pfarreiangehörigen vergrößert wurden und an deren Großzügigkeit appellieren sollten. 
In den gleichen zeitlichen Rahmen fällt auch der gotische Umbau in der Laurentius-Vorstadt, und zwar sowohl der der Pfarrkirche St. Lorenz, als auch die beiden Umbauten der St. Jakobskapelle. Die Grabung an der Friedhofskapelle förderte interessante Funde von Steinmetzzeichen zutage, die vor allem eine Erscheinung der Gotik sind. Eine Gruppe von achtzehn Zeichen machen die Zeichen auf dem Sockelsims der Kapelle, auf dem Sockel der Außenmauern und in sekundären Lagen aus. Sie wurden in drei Kategorien unterteilt, in persönlich gebundene Steinmetzzeichen, in große Zeichen (Meisterzeichen?) und in Versatzzeichen. Im Bereich der durch die Grabung zugänglich gemachten Nord- und Westwand der Kapelle arbeiteten mindestens elf Steinmetze (Zeichen Nr. 1-3 können als identisch gelten, Nr. 7-8 könnte ebenfalls als Steinmetzzeichen bezeichnet werden, Zeichen Nr. 11 ist fraglich).

Analogien zu den Zeichen belegen, dass es Verbindungen in das Gebiet von Bratislava gab, und zwar zur Bauhütte, die am Umbau der Pfarrkirche St. Martin und der Burg beteiligt war. Sie reichten sogar bis ins nahe gelegene Wien (Stefansdom, Minoritenkirche), die den ganzen mitteleuropäischen Raum beeinflussten. Interessant sind die Ähnlichkeiten mit Zeichen im Elisabeth-Dom in Košice, im Veitsdom in Prag und im entfernt gelegenen Dom von Regensburg.

Eine Materialanalyse (Probe Nr. 3) der Steinmetzelemente hat bestätigt, dass der benutzte Sandstein auch an den übrigen zeitgleichen Bauten in Bratislava verwendet wurde und aus heimischen Quellen stammt (Steinbrüche in Bratislava, Devín). Die älteren Steinmetzzeichen bilden gleichzeitig die Kategorie Versatzzeichen und wurden in sekundären Lagen gefunden (eingemauert im Außengemäuer und in der Verfüllung des Beinhauses). Anhand der petrographischen Analyse (Probe Nr. 5) kann angenommen werden, dass man für den Bau im angegebenen Zeitraum auch Steine von älteren, antiken Bauten verwendete, die einst im Raum Bratislava und Umgebung gestanden haben.

Mgr. Petra Šimončičová Koóšová, PhD., Mestský ústav ochrany pamiatok Bratislava, Uršulínska 9, SK 81101 Bratislava, Slovenská republika,almos@post.cz

PhDr. Branislav Lesák, Mestský ústav ochrany pamiatok Bratislava, Uršulínska 9, SK 81101 Bratislava, Slovenská republika, branislav.lesak@gmail.com

Doc. RNDr. Daniel Pivko, PhD., Katedra geológie a paleontológie Prírodovedeckej fakulty Univerzity Komenského v Bratislave, Mlynská dolina, SK 84215 Bratislava IV, Slovenská republika,pivko@fns.uniba.sk 
